\title{
Evaluation of a Heart Failure Telemonitoring Program Through a Microsimulation Model: Cost-Utility Analysis
}

Chris Boodoo ${ }^{1}$, BSc, MSc; Qi Zhang ${ }^{1}$, BSc, MA; Heather J Ross ${ }^{2,3,4}$, MHS, MD; Ana Carolina Alba ${ }^{2,3,4}$, PhD, MD; Audrey Laporte ${ }^{1,5}$, MA, PhD; Emily Seto ${ }^{1,6}$, PEng, PhD

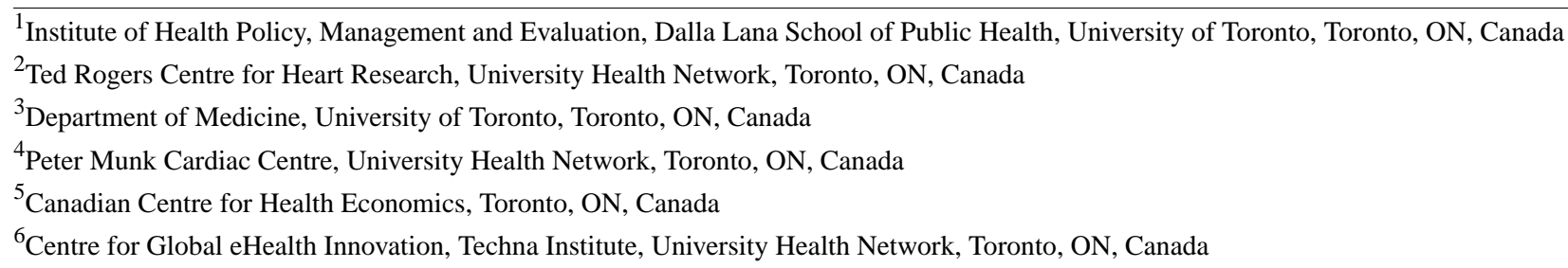

Corresponding Author:

Chris Boodoo, BSc, MSc

Institute of Health Policy, Management and Evaluation

Dalla Lana School of Public Health

University of Toronto

HS Building, 4th Floor

Toronto, ON, M5T 3M6

Canada

Phone: 1 (416) 9784326

Email: c2boodoo@gmail.com

\section{Abstract}

Background: Heart failure (HF) is a major public health issue in Canada that is associated with high prevalence, morbidity, and mortality rates and high financial and social burdens. Telemonitoring (TM) has been shown to improve all-cause mortality and hospitalization rates in patients with HF. The Medly program is a TM intervention integrated as standard of care at a large Canadian academic hospital for ambulatory patients with HF that has been found to improve patient outcomes. However, the cost-effectiveness of the Medly program is yet to be determined.

Objective: This study aims to conduct a cost-utility analysis of the Medly program compared with the standard of care for HF in Ontario, Canada, from the perspective of the public health care payer.

Methods: Using a microsimulation model, individual patient data were simulated over a 25-year time horizon to compare the costs and quality-adjusted life years (QALYs) between the Medly program and standard care for patients with HF treated in the ambulatory care setting. Data were sourced from a Medly Program Evaluation study and literature to inform model parameters, such as Medly's effectiveness in reducing mortality and hospitalizations, health care and intervention costs, and model transition probabilities. Scenario analyses were conducted in relation to HF severity and TM deployment models. One-way deterministic effectiveness analysis and probabilistic sensitivity analysis were performed to explore the impact on the results of uncertainty in model parameters.

Results: The Medly program was associated with an average total cost of Can $\$ 102,508$ (US \$77,626) per patient and total QALYs of 5.51 per patient compared with the average cost of Can \$97,497 (US \$73,831) and QALYs of 4.95 per patient in the Standard Care Group. This led to an incremental cost of Can \$5011 (US \$3794) and incremental QALY of 0.566, resulting in an incremental cost-effectiveness ratio of Can $\$ 8850$ (US \$6701)/QALY. Cost-effectiveness improved in relation to patients with advanced HF and with deployment models in which patients used their own equipment. Baseline and alternative scenarios consistently showed probabilities of cost-effectiveness greater than $85 \%$ at a willingness-to-pay threshold of Can $\$ 50,000$ (US $\$ 37,718$ ). Although the results showed some sensitivity to assumptions about effectiveness parameters, the intervention was found to remain cost-effective.

Conclusions: The Medly program for patients with HF is cost-effective compared with standard care using commonly reported willingness-to-pay thresholds. This study provides evidence for decision makers on the use of TM for HF, supports the use of a 
nurse-led model of TM that embeds clinically validated algorithms, and informs the use of economic modeling for future evaluations of early-stage health informatics technology.

(J Med Internet Res 2020;22(10):e18917) doi: 10.2196/18917

\section{KEYWORDS}

cost utility analysis; cost effectiveness; telemedicine; heart failure; microsimulation; mobile phone

\section{Introduction}

\section{Background}

Heart failure (HF) is a major public health issue with a worldwide prevalence of 26 million and 669,600 in Canada $[1,2]$. Half of those with a diagnosis of HF will die within 5 years, and up to $80 \%$ will die within 10 years [3-5]. Furthermore, flare-ups of HF symptoms occur often and can result in frequent hospitalizations, with more than $50 \%$ of individuals being readmitted within 6 months of discharge [6,7]. Reasons for rehospitalizations include incomplete treatment in hospitals, poor coordination of services or poor communication of care plans at discharge, inadequate access to services, poor patient education, failure to optimize therapies, and lack of long-term monitoring for early signs of worsening health [7]. HF-associated hospital admissions have been estimated to cost the Canadian health care system Can \$482 (US \$364) million in 2013 , and the cost is expected to increase to Can $\$ 720$ (US $\$ 543.14$ ) million by 2030 [8].

It has been recommended that disease management interventions that enable patient empowerment, education, and clinical follow-up should be integrated within the system of care for patients with HF because these interventions have been associated with reduced hospitalization rates and improved quality of life (QoL) and survival [9]. In response, the Medly telemonitoring (TM) system and program, which was deployed to augment the existing standard of care at the Ted Rogers Centre for Heart Research at the University Health Network (UHN), was designed to shift traditional episodic care of HF to a more continuous paradigm where care is extended into the daily lives of patients rather than confined to health care institutions. This program enables patients to record symptoms and physiological measurements, including weight, blood pressure, and heart rate, which are then transmitted to a registered nurse coordinator who reviews and responds to alerts and serves as the first resource for patients. Overall, meta-analyses have shown that TM programs similar to Medly reduce all-cause mortality and hospitalizations when compared with the standard of care without TM [10-14]. However, other studies have also shown null or mixed results for TM [15-18]. Some of this uncertainty in effectiveness can be attributed to the heterogeneity of the studies, such as patient demographics, characteristic differences between the evaluated interventions, and quality of the trial [19].

The decision to implement interventions are often dependent on cost-effectiveness. However, there is a lack of economic evidence for TM stemming from the challenges associated with conducting economic evaluations owing to the heterogeneity and complexity of TM [20,21]. Specifically, diversity stemming from clinical conditions under study, technology, applications, objectives, and context makes comparisons between telemedicine interventions difficult [21]. That said, a number of studies have been conducted that included evaluations of the financial impact of TM for patients with HF, with many reporting savings. However, most studies did not conduct a full economic evaluation [22-33], such as a cost-effectiveness or cost-utility analysis (CUA) [34]. Studies that included a full economic analysis did not evaluate the long-term effects of TM because time horizons of 18 months or less were used [35-37], or the studies were conducted outside of Canada [38-40]. This is owing to the lack of long-term Canadian economic evaluations of TM interventions for patients with HF, information on the life expectancy of this patient population, the possible fluctuations of health status over time, and the nuances of the Canadian population and health care system.

\section{Study Objectives}

The objective of this study was to evaluate the long-term cost-effectiveness of TM for patients with HF within a Canadian context from a public health care payer perspective, referencing costing data and concepts from a TM program, Medly, implemented at a large academic hospital in Ontario, and data from the literature. Specifically, the central research question is as follows: What is the cost utility of the Medly program for patients with HF compared with the standard of care in Ontario? This question will be explored through the application of a microsimulation model.

\section{Methods}

The methods used in this study follow the Consolidated Health Economic Evaluation Reporting Standards [41].

\section{Type of Economic Evaluation}

A CUA was performed. A CUA was chosen because it allows for the effectiveness outcome to be comparable with that of other disease groups and across interventions, making it the gold standard for economic evaluations. Furthermore, there is utility evidence available for patients with HF, allowing for the use of quality-adjusted life years (QALYs) [34].

\section{Target Population}

The target population was a cohort of ambulatory patients with HF from the UHN in Toronto, Canada, enrolled in the Medly Program Evaluation study. Table 1 presents information on the baseline patient characteristics and the missing data. Owing to the limitations associated with manual extraction of data from patients' clinical notes and inconsistent laboratory testing orders, there were considerable missing data. The nature of the missingness was not quantitatively analyzed, and it was assumed that the missing data were randomly distributed. The data reported correspond to the set of variables that were used in the 
Seattle Heart Failure Model (SHFM), which is a multivariate Cox hazard model used to predict mortality [42-45]. As of June $31,2019,315$ patients were enrolled in the program, based on a joint decision between the patient and the cardiologist at either a follow-up outpatient visit or after an inpatient hospital stay.

Table 1. Baseline patient characteristics of the Medly Program Evaluation cohort ( $n=315$; number of patients unless specified otherwise).

\begin{tabular}{|c|c|c|}
\hline Characteristics & Overall & Missing, $\mathrm{n}$ \\
\hline Age (years), mean (SD) & $58.23(15.43)$ & 2 \\
\hline Proportion of females, $\mathrm{n}(\%)$ & $69(22.0)$ & 2 \\
\hline Proportion of ischemic etiology, $\mathrm{n}(\%)$ & $65(28.5)$ & 87 \\
\hline Proportion of beta blockers, n (\%) & $270(89.4)$ & 13 \\
\hline Proportion of aldosterone blockers, $\mathrm{n}(\%)$ & $215(71.2)$ & 13 \\
\hline Proportion of ARBs ${ }^{\mathrm{a}}, \mathrm{n}(\%)$ & $82(27.2)$ & 13 \\
\hline Proportion of $\mathrm{ACE}^{\mathrm{b}}$ inhibitors, $\mathrm{n}(\%)$ & $137(45.5)$ & 13 \\
\hline Proportion of allopurinol, $\mathrm{n}(\%)$ & $41(13.6)$ & 13 \\
\hline Percentage $\mathrm{LVEF}^{\mathrm{c}}$, mean $(\mathrm{SD})$ & $32.07(13.62)$ & 7 \\
\hline New York Health Association (average class), mean (SD) & $2.36(0.59)$ & 13 \\
\hline Systolic blood pressure (mm Hg), mean (SD) & $110.36(17.91)$ & 53 \\
\hline Percentage of lymphocytes, mean (SD) & $22.18(9.07)$ & 52 \\
\hline Sodium (mEq/L), mean (SD) & $137.73(3.06)$ & 33 \\
\hline Cholesterol (mg/dL), mean (SD) & $154.77(52.71)$ & 83 \\
\hline Hemoglobin $(\mathrm{g} / \mathrm{dL})$, mean (SD) & $13.33(1.99)$ & 52 \\
\hline Urate $(\mathrm{mg} / \mathrm{dL})$, mean $(\mathrm{SD})$ & $7.97(2.70)$ & 86 \\
\hline Weight $(\mathrm{kg})$, mean (SD) & $83.39(20.04)$ & 44 \\
\hline Furosemide-equivalent dose (mg/day), mean (SD) & $99.57(123.93)$ & 16 \\
\hline Proportion of implantable cardioverter-defibrillators, $\mathrm{n}(\%)$ & $165(56.5)$ & 23 \\
\hline
\end{tabular}

${ }^{\mathrm{a}} \mathrm{ARB}$ : angiotensin II receptor blocker.

${ }^{\mathrm{b}} \mathrm{ACE}$ : angiotensin-converting-enzyme.

${ }^{\mathrm{c}}$ LVEF: left ventricular ejection fraction.

\section{The Intervention-Medly}

In August 2016, the Medly program was deployed to augment the existing standard of care at the Ted Rogers Centre for Heart Research at the UHN. Patients are trained to use the technology, and the importance of taking daily readings is emphasized. Patients then use the intervention as long as there are clinical benefits as determined by both the clinician and the patient. The program is led by a registered nurse coordinator who reviews and responds to alerts and serves as the first resource for patients' clinical concerns or technical troubleshooting.

The main component of the program is the Medly smartphone app. Patients use the app to record their body weight, blood pressure, and heart rate and to answer a short yes or no questionnaire about their symptoms. Patients are asked to take these readings daily immediately after they wake up. These data are then processed by a clinically validated algorithm to interpret the readings relative to the patient's target thresholds set by the most responsible HF physician [46]. If the algorithm determines that the recordings are within the target range, patients are presented with a prompt stating their HF is in a stable condition. If the algorithm deems that the readings are outside the target range and/or identify an abnormal trend in weight gain, the patient is prompted with self-care feedback such as taking an additional dose of their diuretic medication and to contact their care provider or to visit the emergency department (ED). Figure 1 shows screenshots of some of the various interfaces with which patients interact. In addition to the self-care messages, the registered nurse coordinator receives the alert via email and triages the event. The nurse also responds to technical troubleshooting. A full-time nurse is projected to be able to manage approximately 500 patients through the Medly program. Alerts and all patient TM data can be viewed on the Medly clinical dashboard. Other features of the Medly app include graphical trends of specific measurements and an automated phone call to remind patients to take their daily measurements if it is past $10 \mathrm{AM}$ (can be disabled per patient's request). 
Figure 1. Medly app showing instructions for required readings (screen 1), the symptoms questionnaire (screen 2), and personalized self-care feedback (screen 3).

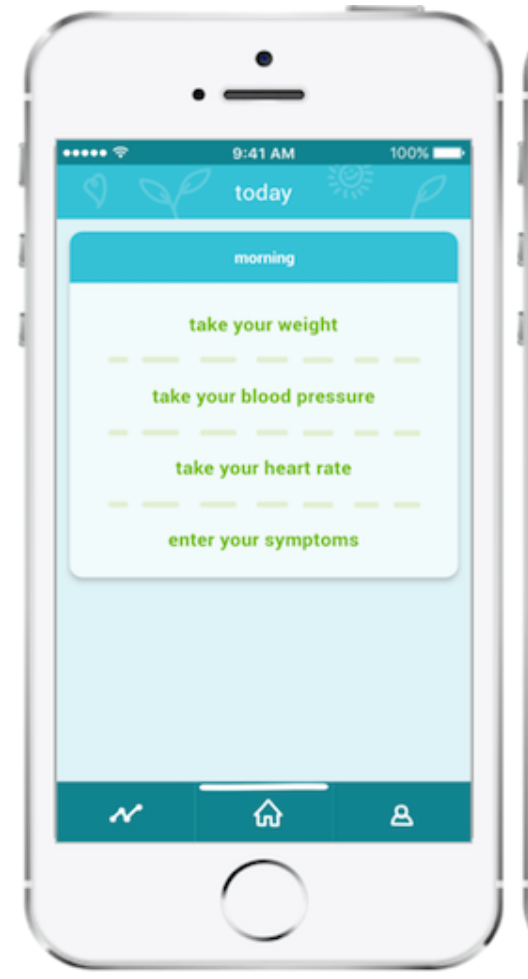

\section{Key Data Source}

This study referenced the ongoing Medly program evaluation, which included multiple pre- and posttest analyses on patient-level impacts, patient adherence, and cost. Quantitative data analyses leverage data that were collected at the 6-month follow-up as a part of the standard of care, such as health care utilization and laboratory results from electronic patient records, while also using data from the TM system. The results of this study have been published in the study by Ware et al (2020) [47], and further details on the study can also be found therein.

\section{Comparators}

In this analysis, the intervention group was a cohort of patients with HF enrolled in the Medly program. The comparator group consisted of patients with HF who received standard care, which does not include the use of TM. It was assumed that standard care was conducted according to the typical care practices in Ontario, which involves specialized multidisciplinary HF clinics, although care models may vary among clinics [48].

\section{Perspective}

This analysis was conducted from the perspective of the public payer, namely the Ontario Ministry of Health because Medly is currently implemented in a publicly funded health care system.

\section{Time Horizon and Discounting}

A time horizon of 25 years was adopted to determine the long-term cost and outcomes associated with Medly for the patient population with HF. Costs and outcomes were discounted at an annual rate of $1.5 \%$, as recommended by the Canadian Agency for Drugs and Technologies in Health [49].

\section{Model Framework, Conceptualization, and Technique}

All analysis and model construction were conducted using RStudio [50]. The model consists of 7 mutually exclusive states: 4 states specific to HF severity, 2 states for hospitalization events, and 1 absorbing state for death. Patients with HF can alternate between a state of decompensation (or symptom exacerbation or functional capacity impairment) and a state of clinical stability. To capture this, the model was stratified by, and allowed for, transitions between New York Health Association (NYHA) functional classes. The NYHA functional classification is a common measure used by clinicians to classify the severity of symptoms in patients with HF, in which a higher class indicates worse health [51]. Hospitalizations mark a fundamental change in the natural history of HF with subsequent increased rehospitalizations and higher mortality rates as the patient's disease progresses [52,53]. A cycle length of 1 month was chosen to account for 30-day readmission rates common in the HF population [54]. As recommended by Naimark et al [55] for models that are relatively simple and have a cycle length of a month or less, a half-cycle correction was omitted.

The modeling technique chosen was a patient-level state-transition model, also known as a first-order Monte Carlo microsimulation. This model was appropriate because it can capture patient heterogeneity that is common in patients with $\mathrm{HF}$ and is also the preferred option for modeling chronic disease [56]. Figure 2 shows the conceptualization of the Markov model that was developed to represent an individual's progression of HF. 
Figure 2. Conceptual representation of the microsimulation model structure. States 1 to 4 represent the transitions between New York Health Association classes. States 5 and 6 show transitions into and between hospitalization states. State 7 is an absorbing state representing death, where all states can transition to. NYHA: New York Health Association.

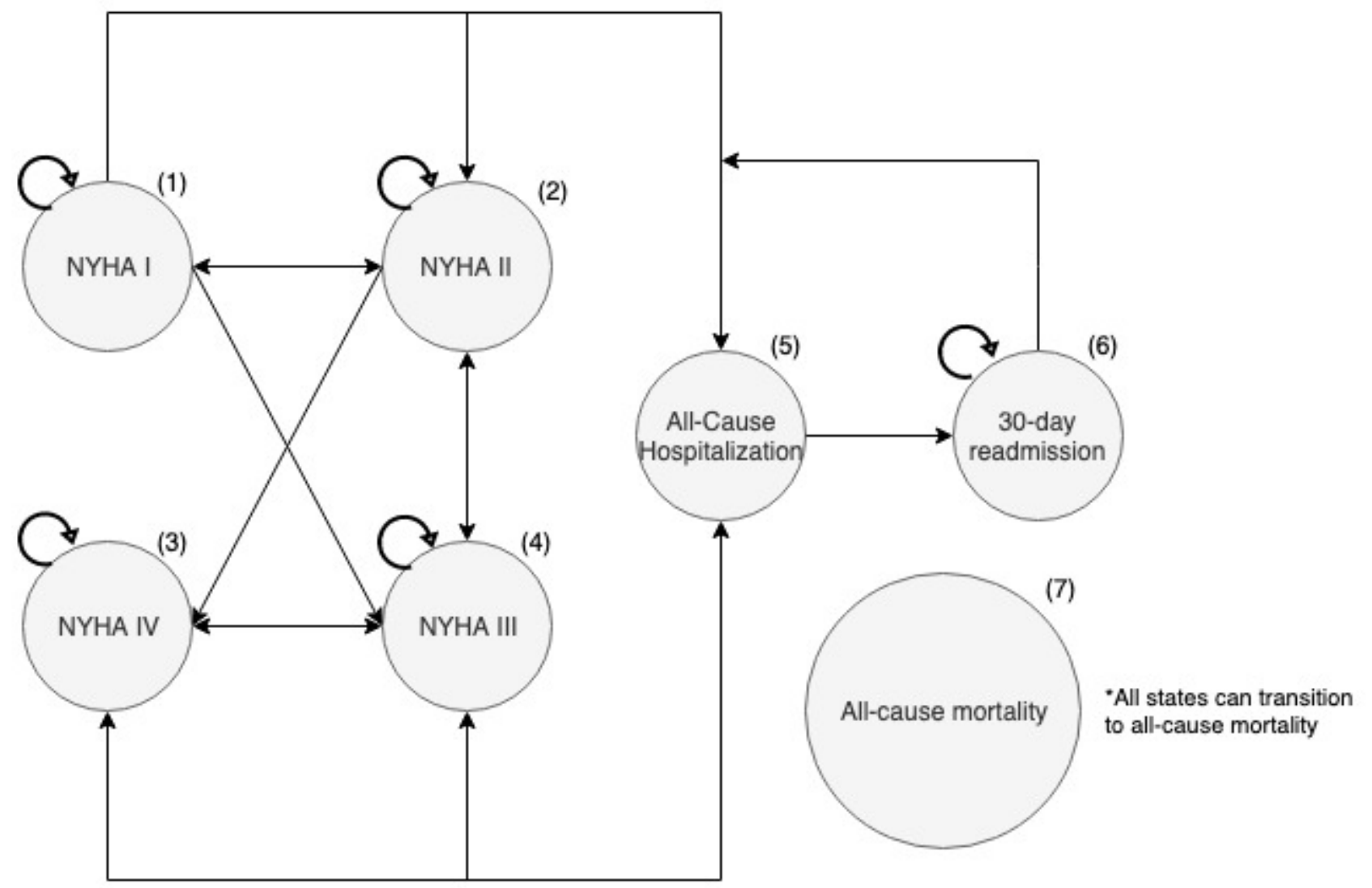

\section{Parameter Estimates}

The values used in the model were based on a literature review. The values inputted into the model are conditional on patient characteristics. Patients with a more limited functional capacity by NYHA class have a higher risk of hospitalization [57-61]. In addition, the risk for readmission is highest within 30 days of hospital discharge [52]. As a patient's NYHA functional class can change over time, the probability of transitioning between classes was derived from the large-scale international SENIORS study [62,63]. All-cause mortality during hospitalization was based on the study by Yeung et al (2012) [64]. The SHFM was used to derive a survival curve for each patient over their lifetime, which is a multivariate Cox hazard model that has been validated on multiple cohorts of patients with HF [42-45].

\section{Generating Virtual Patient Profiles}

To generate virtual patient profiles, a Cholesky decomposition was performed on a correlation matrix that describes the interdependence between patient characteristics [56]. The matrix was derived from a consolidated representative sample of 7125 patients with HF from the University of Washington, Prospective Randomized Amlodipine Survival Evaluation, Valsartan Heart Failure Trial, and Italian Hearty Failure Registry [65] (Multimedia Appendix 1). Values for each patient characteristic were sampled from a multivariate normal distribution, defined by the Medly Program Evaluation cohort's mean and SD in Table 1 using the R-package "PoisBinOrdNonNor" [66,67].
Patient characteristics included clinical, pharmacological, device, and laboratory data, based on the SHFM developed by Levy et al (2006) [43].

\section{Effectiveness}

The 2 primary outcomes that TM interventions for patients with $\mathrm{HF}$ aim to improve are all-cause mortality and all-cause hospitalization rates. The risk of all-cause hospitalization was based on evidence from the Medly program evaluation, which reported a relative risk (RR) of 0.753 (95\% CI 0.634-0.879) for patients using Medly (Multimedia Appendix 1; All-cause hospitalization). Owing to the lack of an interdependent comparative group and small sample size of the Medly program evaluation, it was not possible to evaluate its effectiveness in reducing mortality. Therefore, the estimate was based on a meta-analysis of the effectiveness of TM for patients with HF by Yun et al (2018) [11]. This meta-analysis only included randomized controlled trials that defined TM as the transmission of biological information, such as body weight, heart rate, and blood pressure via telecommunication technologies. Owing to this strict inclusion criteria, it was deemed comparable evidence for the expected benefits that Medly users could experience. It was reported that TM users had an RR of $0.81(0.70-0.94)$ for all-cause mortality compared with 416 of 3724 patients in the TM group to 483 of 3733 patients in the control group [11]. The study follow-up periods ranged from 3 months to 15 months, with 1 study having a 4 year follow-up. The meta-analysis also presented a subgroup analysis of only asynchronous interventions (ie, removal of real-time and 
teleconferencing technologies), where an RR of 0.79 (0.66-0.94) was reported for all-cause mortality, which is similar to the primary analysis.

\section{Measurement and Evaluation of Health}

Each state in the model has an associated utility value between 0 and 1 . Utility values for each health state were derived on the basis of values from other health economic evaluations of $\mathrm{HF}$ interventions. NYHA classes are commonly used to categorize patients with HF based on severity of symptoms, and studies have estimated utility values for each class $[60,62,68,69]$. All utilities and the sources of the values are presented in Table 2. To adjust for the decrease in the QoL patients experience when hospitalized [70], the patient utility value in the model was decreased by 0.059 in the hospitalization state, consistent with Sandhu et al (2016) [71].

Table 2. Model parameters conditional on New York Health Association (NYHA) class including living with heart failure costs (in Can currency), utilities, probability of hospitalization, and transitions between NYHA classes.

\begin{tabular}{|c|c|c|c|c|c|c|}
\hline Description & NYHA $^{\mathrm{a}}$ I & NYHA II & NYHA III & NYHA IV ${ }^{b}$ & Source & Distribution \\
\hline \multicolumn{7}{|l|}{ Health care costs } \\
\hline $\begin{array}{l}\text { Emergency department costs, } \\
\text { Can \$ (US \$) }\end{array}$ & 0.00 & 0.00 & $62.83(47.20)$ & $62.83(47.20)$ & Medly Program Evaluation & Gamma \\
\hline $\begin{array}{l}\text { General practitioner visit costs, } \\
\text { Can \$ (US \$) }\end{array}$ & 0.00 & 0.00 & $12.87(9.67)$ & $12.87(9.67)$ & Medly Program Evaluation & Fixed \\
\hline $\begin{array}{l}\text { Drug costs (only if patient age } \\
\text { is } \geq 65 \text { ), Can } \$ \text { (US } \$ \text { ) }\end{array}$ & $\begin{array}{l}52.00 \\
(39.06)\end{array}$ & $52.00(39.06)$ & $79.43(59.67)$ & $\begin{array}{l}208.16 \\
(156.38)\end{array}$ & Kaul et al (2011) [72] & Gamma \\
\hline Outpatient costs, Can \$ (US \$) & $\begin{array}{l}97.00 \\
(72.87)\end{array}$ & $97.00(72.87)$ & $97.00(72.87)$ & $97.00(72.87)$ & Medly Program Evaluation & Gamma \\
\hline $\begin{array}{l}\text { Total monthly cost of living } \\
\text { with heart failure, Can \$ (US } \\
\text { \$) }\end{array}$ & $\begin{array}{l}149.00 \\
(111.94)\end{array}$ & $149.00(111.94)$ & $252.13(189.42)$ & $\begin{array}{l}380.86 \\
(286.14)\end{array}$ & $\begin{array}{l}\mathrm{OCCI}^{\mathrm{c}}[73], \mathrm{SOB}^{\mathrm{d}}[74] \text {, } \\
\text { Kaul et al (2011) [72] }\end{array}$ & $\mathrm{N} / \mathrm{A}^{\mathrm{e}}$ \\
\hline \multicolumn{7}{|l|}{ Utilities (range) } \\
\hline Living with heart failure & $\begin{array}{l}0.81(0.81- \\
0.90)\end{array}$ & $0.72(0.72-0.83)$ & $0.59(0.59-0.74)$ & $\begin{array}{l}0.508(0.508- \\
0.59)\end{array}$ & Yao et al (2008) [62] & Beta \\
\hline $\begin{array}{l}\text { Probability of all-cause hospital- } \\
\text { ization }\end{array}$ & $\begin{array}{l}0.0152 \\
(0.008- \\
0.023)\end{array}$ & $\begin{array}{l}0.024(0.012- \\
0.036)\end{array}$ & $\begin{array}{l}0.024(0.012- \\
0.036)\end{array}$ & $\begin{array}{l}0.154(0.077- \\
0.231)\end{array}$ & $\begin{array}{l}\text { Ford et al (2012) [68], } \\
\text { Borisenko et al (2015) [69] }\end{array}$ & Beta \\
\hline \multicolumn{7}{|c|}{ Transition probabilities between NYHA classes (probability) } \\
\hline NYHA I & 0.977 & 0.019 & 0.004 & 0 & $\begin{array}{l}\text { Flather et al (2005) [63], } \\
\text { Yao et al (2008) [62] }\end{array}$ & Dirichlet \\
\hline NYHA II & 0.008 & 0.981 & 0.01 & 0.001 & $\begin{array}{l}\text { Flather et al (2005) [63], } \\
\text { Yao et al (2008) [62] }\end{array}$ & Dirichlet \\
\hline NYHA III & 0 & 0.034 & 0.96 & 0.006 & $\begin{array}{l}\text { Flather et al (2005) [63], } \\
\text { Yao et al (2008) [62] }\end{array}$ & Dirichlet \\
\hline NYHA IV & 0 & 0 & 0.055 & 0.945 & $\begin{array}{l}\text { Flather et al (2005) [63], } \\
\text { Yao et al (2008) [62] }\end{array}$ & Dirichlet \\
\hline
\end{tabular}

${ }^{\mathrm{a}}$ NYHA: New York Health Association.

${ }^{\mathrm{b}}$ NYHA IV assumed same as NYHA III, except drug cost.

${ }^{\mathrm{c}}$ OCCI: Ontario Case Costing Initiative.

${ }^{\mathrm{d}} \mathrm{SOB}$ : Schedule of Benefits for Physician Services.

e N/A: not applicable.

\section{Resource Use and Costs}

Health care utilization was based on data from the Medly program evaluation, and hospitalization and ED visit costs were derived from the Ontario Case Costing Initiative (OCCI) report for 2017-2018 using diagnosis codes I500, I509, and I501 [73]. The unit cost per outpatient visit was based on a paper outlining health care utilization for patients with HF over the last 6 months of their lives by Kaul et al (2006) [72] in a comparable health care system in Alberta. This was based on the provincial

ambulatory care case mix group, which captures direct and indirect functional center costs [75]. Physician fees for general practitioner (GP) visits were based on billing code A005 in Ontario's Schedule of Benefits [74]. The unit costs were multiplied by utilization data from the Medly program evaluation to calculate the monthly costs (Table 3). Median values for utilization were used because the distribution of health care utilization is typically left-skewed [76]. Monthly drug costs were incurred on the part of the public payer under the Ontario Drug Benefit program for patients aged 65 years and older. The 
monthly drug costs were calculated on the basis of the costs reported in Kaul et al (2006).

Of note, the number of outpatient visits for both the intervention and comparator-simulated cohorts was limited to those that occurred at UHN because information outside of UHN's services was unavailable at the time of the study. Furthermore, self-reported ED visits were used because UHN patient records may underreport the true number of ED visits as patients may live at some distance from UHN and may instead visit a community hospital for an emergency. Self-reported GP visits were used because UHN data do not record this information.

Table 3. Median health care utilization over 6 months before using Medly, unit costs per service (in Can currency), and associated distribution stratified by New York Health Association (NYHA) classes. $\mathrm{N}$ is the number of patients in each NYHA class.

\begin{tabular}{|c|c|c|c|c|c|c|c|}
\hline Type of resource & $\begin{array}{l}\text { Unit cost, mean } \\
\text { (SD), Can \$ }\end{array}$ & $\begin{array}{l}\text { Source for unit } \\
\text { cost }\end{array}$ & $\begin{array}{l}\text { NYHA I health } \\
\text { care utilization } \\
(\mathrm{n}=44)\end{array}$ & $\begin{array}{l}\text { NYHA II health } \\
\text { care utilization } \\
(n=166)\end{array}$ & $\begin{array}{l}\text { NYHA III } \\
\text { health care uti- } \\
\text { lization }(n=93)\end{array}$ & $\begin{array}{l}\text { NYHA IV } \\
\text { health care uti- } \\
\text { lization }(n=1)\end{array}$ & Distribution \\
\hline $\begin{array}{l}\text { Emergency depart- } \\
\text { ment (self-reported) }\end{array}$ & $377.00(374.00)$ & $\begin{array}{l}\text { Ontario Case } \\
\text { Costing Initia- } \\
\text { tive }\end{array}$ & 0 & 0 & 1 & $-^{\mathrm{a}}$ & $\begin{array}{l}\text { Negative bino- } \\
\text { mial }\end{array}$ \\
\hline Outpatient visit & $291.33(161.11)$ & $\begin{array}{l}\text { Kaul et al } \\
\text { (2011) [72] }\end{array}$ & 2 & 1 & 2 & - & $\begin{array}{l}\text { Negative bino- } \\
\text { mial }\end{array}$ \\
\hline $\begin{array}{l}\text { General practitioner } \\
\text { visit (self-reported) }\end{array}$ & 77.20 & $\begin{array}{l}\text { Schedule of } \\
\text { Benefits }\end{array}$ & 0 & 1 & 2 & - & $\begin{array}{l}\text { Negative bino- } \\
\text { mial }\end{array}$ \\
\hline $\begin{array}{l}\text { Drug costs over } 6 \\
\text { months }\end{array}$ & $\begin{array}{l}1248.96 \\
(2233.52)\end{array}$ & $\begin{array}{l}\text { Kaul et al } \\
\text { (2011) [72] }\end{array}$ & - & - & - & - & Gamma \\
\hline
\end{tabular}

${ }^{\mathrm{a}}$ No data available.

\section{Medly Costs and Deployment Models}

Costs related to implementation and maintenance of Medly were provided by the Medly project management and development team (Table 4). The fixed costs associated with implementation were based on a system that delivers care to 1000 patients. The operational cost per patient included costs associated with asset management (technical and application support) and on-site frontline support for patients and clinicians, which was delivered via 2 registered nurse coordinators hired by the Medly program. Two registered nurses were included according to the Medly project management team's cost projections for 1000 patients. This is similar to what was reported by Ware et al (2020) [47], where approximately 300 patients were managed by 1 registered nurse coordinator. The variable cost per patient included the cost of the device and equipment, depending on the equipment that was loaned to the patient. The costs of the device and the equipment were based on a rental model. These costs were adjusted for monthly costs according to the cycle length of the model.

The variable cost was based on a mix of models where users can fall into 1 of the 3 categories: Full Kit (FK), Bring Your Own Phone (BYOP), and Bring Your Own Everything (BYOE). An FK user refers to a user who was provided with all necessary equipment for the technology, which is currently funded by the Medly program, including a smartphone with a data plan, blood pressure monitor, weight scale, and licensing fee. A BYOP user brings their own phone and pays for their own data plan, but the blood pressure monitor, weight scale, and licensing fee are provided by the Medly program. The BYOE user brings their own equipment and is provided with just the licensing fee by the program. The reference case analysis uses a ratio of $2 \mathrm{FK}: 1$ BYOP:2 BYOE, which was based on the number of each category of users in Medly's current implementation. All costs were converted to 2019 Canadian dollars using Statistics Canada's Consumer Price Index to adjust for inflation [77]. 
Table 4. Parameter estimates not conditional on the New York Health Association class including hospitalization costs (in Can currency) and disutility, readmission rates, Medly costs (in Can currency), and Medly effectiveness estimates.

\begin{tabular}{|c|c|c|c|}
\hline Parameters & Value & Source & Distribution \\
\hline \multicolumn{4}{|l|}{ Costs } \\
\hline Hospitalization cost per admission (Can \$), mean (SD) & $8908(16,867)$ & $\mathrm{OCCI}^{\mathrm{a}}$ & Gamma \\
\hline Hospitalization length of stay days, mean (SD) & $5.9(11.2)$ & OCCI & Log normal \\
\hline Medly fixed costs for site implementation & 102,500 & Medly program & Fixed \\
\hline Medly operational cost per patient (cost per month), Can \$ & 44.67 & Medly program & Fixed \\
\hline Medly Full Kit cost per patient (cost per month), Can \$ & 67.56 & Medly program & Fixed \\
\hline Medly Bring-Your-Own-Phone cost per patient (cost per month), Can $\$$ & 18.87 & Medly program & Fixed \\
\hline $\begin{array}{l}\text { Medly Bring-Your-Own-Everything cost per patient (cost per month), } \\
\text { Can \$ }\end{array}$ & 3.80 & Medly program & Fixed \\
\hline \multicolumn{4}{|l|}{ Hospitalization, probability } \\
\hline 30-day readmission probability $(95 \% \mathrm{CI})$ & $0.159(0.089-0.159)$ & Yeung et al (2012) [64] & Beta \\
\hline Disutility for hospitalization ( $95 \% \mathrm{CI}$ ) & $0.059(0-0.11)$ & Sandhu et al (2015) [71] & Beta \\
\hline \multicolumn{4}{|l|}{ Medly treatment effect, disutility } \\
\hline $\mathrm{RR}^{\mathrm{b}}$ for hospitalization & $0.857(0.703-1.014)$ & Medly & Log normal \\
\hline RR for morality & $0.81(0.70-0.94)$ & Yun et al (2018) [13] & Log normal \\
\hline
\end{tabular}

${ }^{\mathrm{a} O C C I}$ : Ontario Case Costing Initiative.

${ }^{b}$ RR: relative risk.

\section{Reference Case Analysis}

The expected values for all model parameters were used for the deterministic analysis. The cohort size was assumed to be 1000 patients. Each simulated patient progressed through the model twice until death; once as a patient using Medly and again as a patient receiving standard care. Each patient incurred costs and QALYs depending on the health state they were in. Total costs and QALYs were summed for both the Medly simulations and standard care simulations. From this, the average incremental cost-effectiveness ratio (ICER) per patient was computed using the following formula:

$$
I C E R=\frac{\text { Total Cost of Medly }- \text { Total Cost of Standard of Care }}{\text { Total QALY Medly-Total QALY Standard of Care }}
$$

Monte Carlo standard errors were also reported to show how the results vary owing to patient heterogeneity and randomness introduced from patients transitioning to each state.

A second-order probabilistic analysis was also conducted to characterize the uncertainty in the deterministic results. Each parameter in the model was assigned a distribution based on the nature of the input parameter [56]. R-package "fitdistrplus" was used to fit negative binomial distributions for the health care utilization data from the Medly program evaluation via maximum likelihood estimation [78]. Details regarding how distributions were chosen based on Akaike Information Criterion and Bayesian Information Criterion scores are available in Multimedia Appendix 1 ([11,54]; Curve fitting). Values were then randomly selected from the respective distributions and assigned as the input parameter. This process was repeated 1000 times. The results for each iteration were plotted on a cost-utility plane to visualize whether Medly was cost-effective, cost-saving, cheaper, or dominated. The simulations were also plotted onto a cost-effectiveness acceptability curve (CEAC), where the proportion of simulations that resulted in an ICER under a range of willingness-to-pay (WTP) thresholds are plotted. A commonly used WTP threshold is Can $\$ 50,000$ (US $\$ 37,718) / Q A L Y[79,80]$.

\section{Scenario Analyses}

\section{NYHA Functional Classes}

Currently, most patients enrolled in the Medly program have HF that corresponds to NYHA functional classes II or III. For this scenario analysis, cohorts were generated for NYHA functional classes I, II, and III and simulated deterministically and probabilistically. NYHA functional class IV was not included because only 1 functional class IV patient was enrolled in the Medly program. Average ICERs per NYHA functional class were calculated in both the deterministic and probabilistic models, and CEAC curves were produced on a plot to visualize for which classes Medly was most likely to be cost-effective.

\section{Deployment Model}

As mentioned, the Medly program currently offers 3 types of kits where the ratio of types of user is 2:1:2 for FK, BYOP, and BYOE, respectively. As the Medly program expands, understanding how the ICER changes when costs are shifted from the public dollar to the individual is informative to decision makers. Therefore, this analysis explored various proportions of user types. Specifically, each patient in the reference case cohort was randomly assigned $\mathrm{FK}, \mathrm{BYOP}$, and BYOE according to predefined ratios. The ratios of interest were 1:0:0 (100\% FK), 1:4:5 (40\% BYOP, 50\% BYOE), and 0:0:1 (100\% BYOE). 
These were identified as all FK, mixed deployment, and all BYOE, respectively.

\section{Effectiveness}

One-way deterministic analyses were also conducted to address the uncertainty associated with the estimates for Medly's effectiveness in reducing all-cause hospitalizations (RR 0.63-0.88) and mortality (RR 0.70-0.94). Specifically, 95\% CI for each estimate were inputted into the model, and the range of ICERs was presented.

\section{Results}

\section{Reference Case Analysis}

\section{Deterministic Results}

Over a 25-year time horizon, the average total costs were Can $\$ 97,497$ (US $\$ 73,547.84$ ) for the comparator group and Can $\$ 102,508$ (US \$77,327.93) for patients using Medly. The average total QALYs gained were 4.95 and 5.51 for the comparator group and Medly patients, respectively. When comparing the 2 groups, there was an incremental cost of Can \$5011 (US $\$ 3780.10)$ with an incremental QALY gained of 0.566. This resulted in an ICER of Can $\$ 8850$ (US \$6676.09)/QALY (Table 5).

Table 5. Deterministic results of the reference case analysis.

\begin{tabular}{|c|c|c|c|c|c|c|c|c|c|}
\hline Reference & $\begin{array}{l}\text { Costs, Can \$ } \\
\text { (US \$) }\end{array}$ & $\begin{array}{l}\operatorname{MCSE}^{\mathrm{a}}, \mathrm{Can} \\
\text { \$(US \$) }\end{array}$ & QALYs $^{\mathrm{b}}$ & MCSE & $\begin{array}{l}\text { Incremental cost, } \\
\text { Can \$ (US \$) }\end{array}$ & $\begin{array}{l}\text { MCSE, Can \$ } \\
\text { (US \$) }\end{array}$ & $\begin{array}{l}\text { Incremental } \\
\text { QALYs }\end{array}$ & MCSE & $\begin{array}{l}\text { ICER }^{\mathrm{c}}, \text { Can } \$ \\
\text { (US \$; } \\
\text { \$/QALY) }\end{array}$ \\
\hline Comparator & $\begin{array}{l}97,497 \\
(73,831)\end{array}$ & 3948 (2989) & 4.95 & 0.12 & $\mathrm{~N} / \mathrm{A}^{\mathrm{d}}$ & N/A & N/A & N/A & N/A \\
\hline Medly & $\begin{array}{l}102,508 \\
(77,626)\end{array}$ & $3592(2720)$ & 5.51 & 0.13 & $5011(3794)$ & 2014 (1525) & 0.57 & 0.05 & 8850 (6701) \\
\hline
\end{tabular}

${ }^{a}$ MCSE: Monte Carlo standard error.

${ }^{\mathrm{b}} \mathrm{QALY}$ : quality-adjusted life year.

${ }^{\mathrm{c}}$ ICER: incremental cost-effectiveness ratio.

${ }^{\mathrm{d}} \mathrm{N} / \mathrm{A}$ : not applicable.

\section{Probabilistic Results}

On the basis of 1000 simulations of the reference case scenario in which each parameter was sampled from their respective distribution, $81.6 \%(816 / 1000)$ of the simulations showed that
Medly was costlier and more effective, whereas $17.3 \%$ (173/1000) showed that Medly was less costly and more effective (Figure 3). The CEAC in Figure 4 shows that $90.1 \%$ $(901 / 1000)$ of the simulations resulted in an ICER below the Can \$50,000 (US \$37,718)/QALY threshold. 
Figure 3. Cost-utility plane of 1000 iterations from the reference case probabilistic analysis. QALY: quality-adjusted life years.

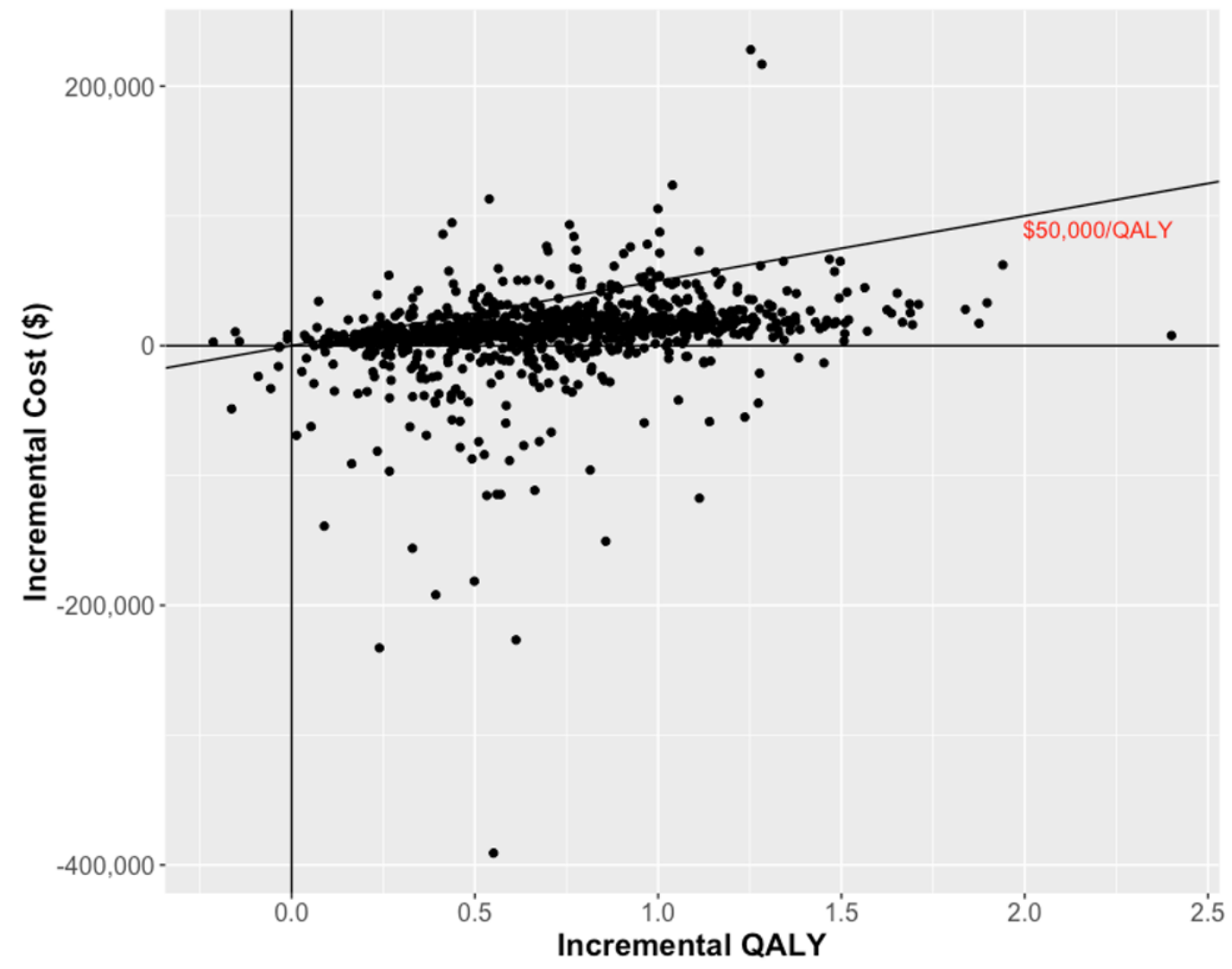

Figure 4. Cost-effectiveness acceptability curve of reference case probabilistic analysis.

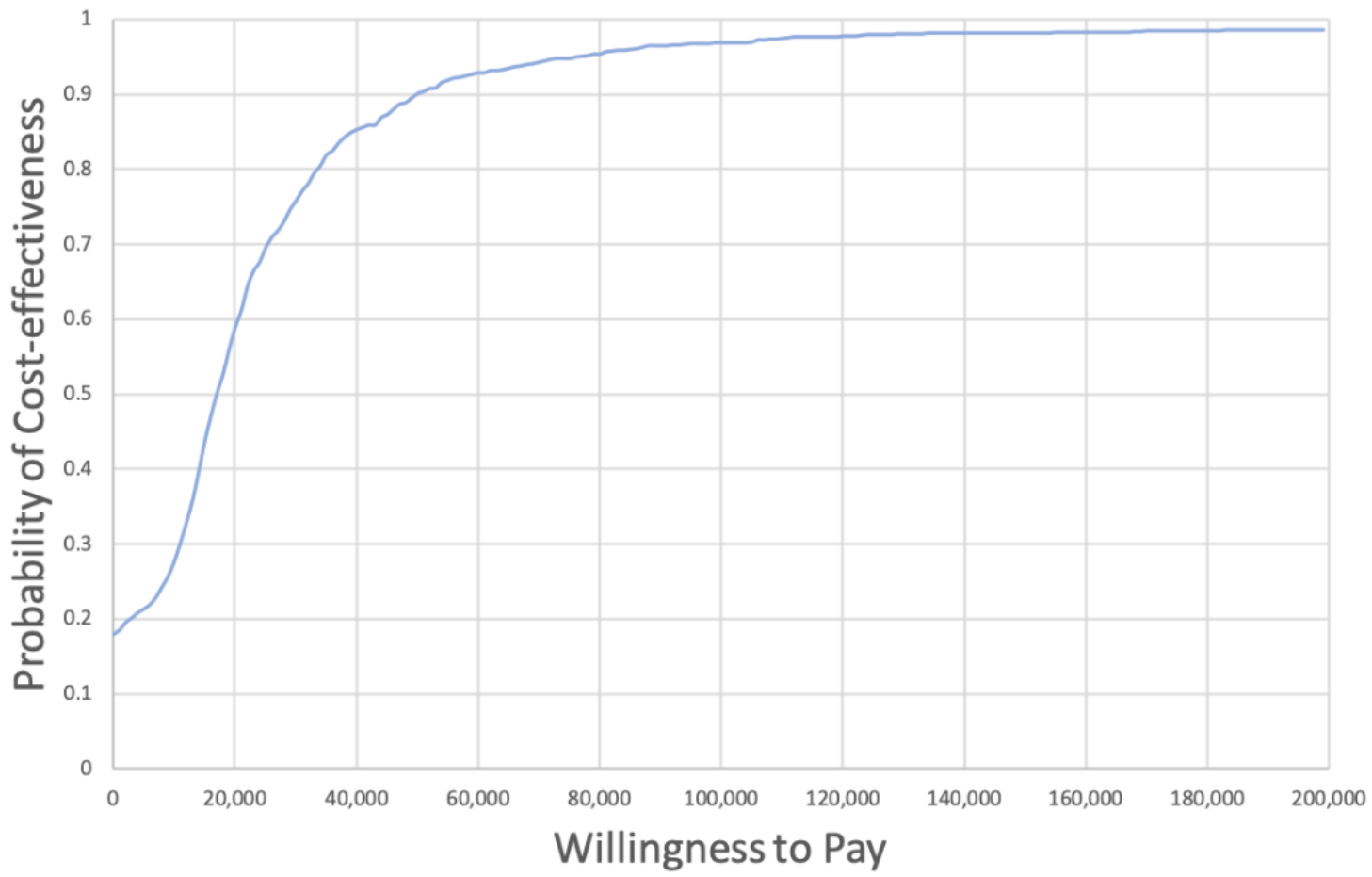

\section{Scenario Analyses}

\section{NYHA Functional Classes}

Table 6 presents the results of the NYHA functional class scenario analyses. As NYHA functional class increased, the average total costs and incremental costs increased. In addition, as NYHA functional class increased, total QALYs per population decreased. This led to a decreasing trend in ICERs with increasing NYHA functional class. 
Table 6. Deterministic results for New York Health Association classes I, II, and III.

\begin{tabular}{|c|c|c|c|c|c|c|c|c|c|}
\hline NYHA $^{\mathrm{a}}$ classes & $\begin{array}{l}\text { Costs, Can \$ } \\
\text { (US \$) }\end{array}$ & $\begin{array}{l}\mathrm{MCSE}^{\mathrm{b}}, \mathrm{Can} \\
\text { \$(US \$) }\end{array}$ & QALYs $^{\mathrm{c}}$ & MCSE & $\begin{array}{l}\text { Incremental cost, } \\
\text { Can \$ (US \$) }\end{array}$ & $\begin{array}{l}\text { MCSE, Can \$ } \\
\text { (US \$) }\end{array}$ & $\begin{array}{l}\text { Incremental } \\
\text { QALYs }\end{array}$ & MCSE & $\begin{array}{l}\text { ICER }^{\mathrm{d}}, \text { Can } \$ \\
\text { (US \$; \$/QALY) }\end{array}$ \\
\hline \multicolumn{10}{|l|}{ NYHA I } \\
\hline Comparator & $\begin{array}{l}81,714 \\
(61,641)\end{array}$ & 3417 (2577) & 6.89 & 0.13 & $\mathrm{~N} / \mathrm{A}^{\mathrm{e}}$ & N/A & N/A & N/A & N/A \\
\hline Medly & $\begin{array}{l}88,016 \\
(66395)\end{array}$ & $3215(2425)$ & 7.48 & 0.14 & $6302(4753)$ & $1806(1362)$ & 0.60 & 0.05 & $10,567(7971)$ \\
\hline \multicolumn{10}{|l|}{ NYHA II } \\
\hline Comparator & $\begin{array}{l}88,405 \\
(66,689)\end{array}$ & $3821(2882)$ & 5.65 & 0.12 & N/A & N/A & N/A & N/A & N/A \\
\hline Medly & $\begin{array}{l}94,335 \\
(71,162)\end{array}$ & $3521(2656)$ & 6.35 & 0.13 & $5930(4473)$ & 2014 (1519) & 0.70 & 0.06 & $8510(6419)$ \\
\hline \multicolumn{10}{|l|}{ NYHA III } \\
\hline Comparator & 104,421 & 4356 & 4.12 & 0.11 & N/A & N/A & N/A & N/A & N/A \\
\hline Medly & 107,803 & 3929 & 4.69 & 0.11 & 3382 & 2134 & 0.57 & 0.05 & 5931 \\
\hline
\end{tabular}

${ }^{a}$ NYHA: New York Health Association.

${ }^{b}$ MCSE: Monte Carlo standard error.

${ }^{\mathrm{c}}$ QALY: quality-adjusted life year.

${ }^{\mathrm{d}}$ ICER: incremental cost-effectiveness ratio.

${ }^{\mathrm{e}} \mathrm{N} / \mathrm{A}$ : not applicable.

The CEAC curves for NYHA functional classes I, II, and III functional classes I, II, and III was 90.5\% (905/1000), 90.6\% are shown in Figure 5. At a WTP threshold of \$50,000 (US (906/1000), and 87.5\% (875/1000), respectively.

$\$ 37,718)$, the probability of cost-effectiveness for NYHA 
Figure 5. Cost-effectiveness acceptability curve of the New York Health Association functional class scenario analyses. CEAC: cost-effectiveness acceptability curve; NYHA: New York Health Association.

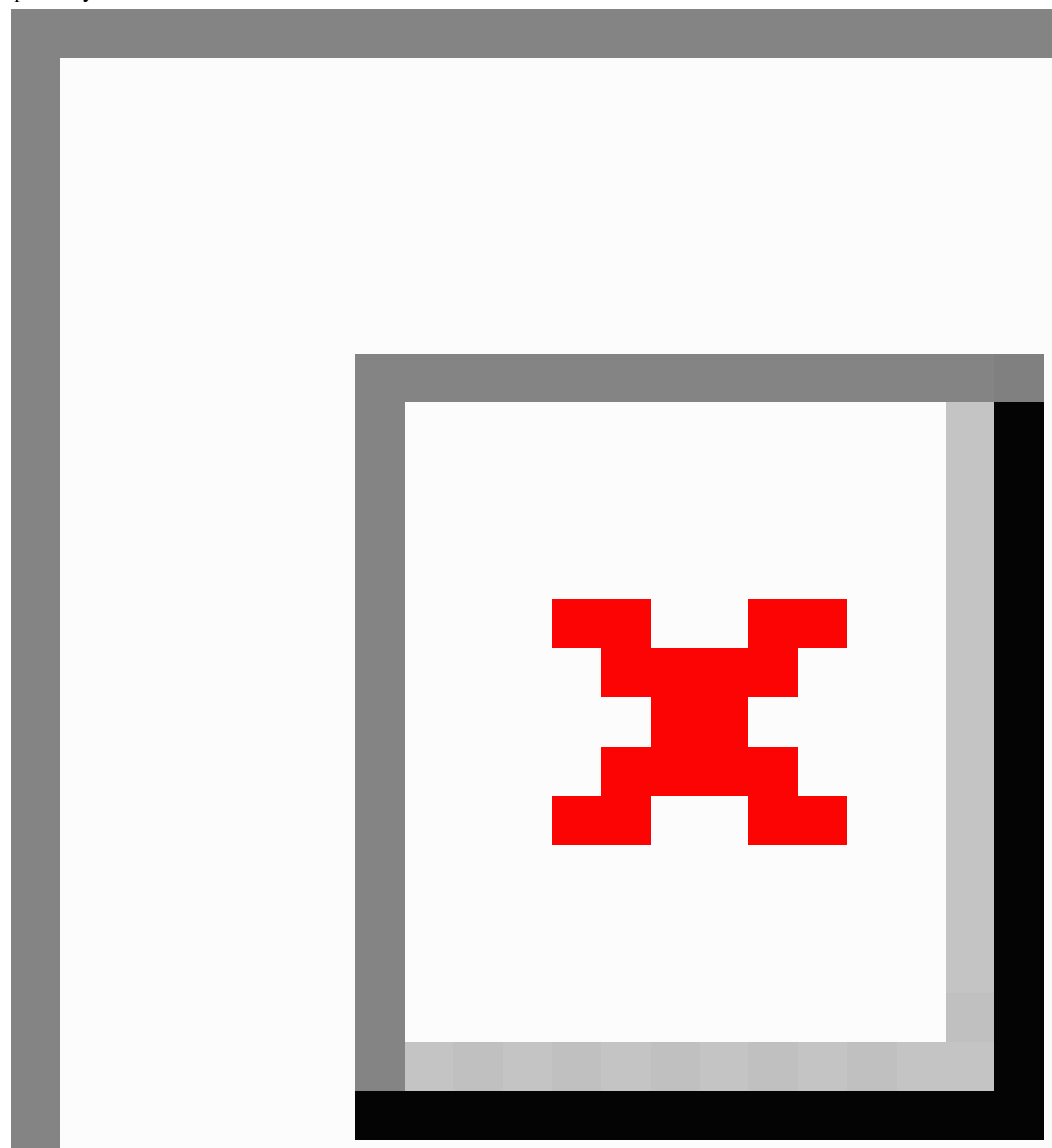

\section{Deployment Models}

Table 7 shows the results of the deployment model scenario analyses. As the only difference between scenarios was the total cost incurred by the Medly group, all comparator groups had the same average total costs and average total QALYs. The average total QALYs for patients using Medly were also the same for all scenarios. Moreover, as expected, when the proportion of FK users increased, so did the average total costs for patients using Medly. This led to ICERs following the same trend.

The CEAC curves for each deployment model are shown in Figure 6. At a WTP threshold of Can \$50,000 (US \$37,718), the probability of cost-effectiveness for all BYOE, mixed model, and all FK was $92.9 \%$ (929/1000), 91.7\% (917/1000), and 85.4\% (854/1000), respectively. 
Table 7. Deterministic results for each deployment model of Medly.

\begin{tabular}{|c|c|c|c|c|c|c|c|c|c|}
\hline $\begin{array}{l}\text { Deployment } \\
\text { models }\end{array}$ & Costs $($ Can $\$)$ & $\operatorname{MCSE}^{\mathrm{a}}(\operatorname{Can} \$)$ & QALYs $^{\mathrm{b}}$ & MCSE & $\begin{array}{l}\text { Incremental } \\
\text { cost (Can \$) }\end{array}$ & $\operatorname{MCSE}(\operatorname{Can} \$)$ & $\begin{array}{l}\text { Incremental } \\
\text { QALYs }\end{array}$ & MCSE & $\begin{array}{l}\mathrm{ICER}^{\mathrm{c}}(\mathrm{Can} \\
\$ / \mathrm{QALY})\end{array}$ \\
\hline \multicolumn{10}{|c|}{ All Bring Your Own Entertainment } \\
\hline Comparator & 97,497 & 3948 & 4.95 & 0.12 & $\mathrm{~N} / \mathrm{A}^{\mathrm{d}}$ & N/A & N/A & N/A & N/A \\
\hline Medly & 99,393 & 3542 & 5.51 & 0.13 & 1896 & 2006 & 0.57 & 0.05 & 3349 \\
\hline \multicolumn{10}{|l|}{ Mixed model } \\
\hline Comparator & 97,497 & 3948 & 4.947 & 0.12 & N/A & N/A & N/A & N/A & N/A \\
\hline Medly & 100,769 & 3567 & 5.51 & 0.13 & 3273 & 2007 & 0.57 & 0.05 & 5780 \\
\hline \multicolumn{10}{|l|}{ All Full Kit } \\
\hline Comparator & 97,497 & 3948 & 4.947 & 0.12 & N/A & N/A & N/A & N/A & N/A \\
\hline Medly & 106,194 & 3646 & 5.51 & 0.13 & 8697 & 2015 & 0.57 & 0.05 & 15,362 \\
\hline
\end{tabular}

${ }^{a}$ MCSE: Monte Carlo standard error.

${ }^{\mathrm{b}} \mathrm{QALY}$ : quality-adjusted life year.

${ }^{\mathrm{c}}$ ICER: incremental cost-effectiveness ratio.

${ }^{\mathrm{d}} \mathrm{N} / \mathrm{A}$ : not applicable.

Figure 6. Cost-effectiveness acceptability curves for each deployment model in the scenario analyses. BYOE: Bring Your Own Everything; CEAC: cost-effectiveness acceptability curve; FK: Full Kit.

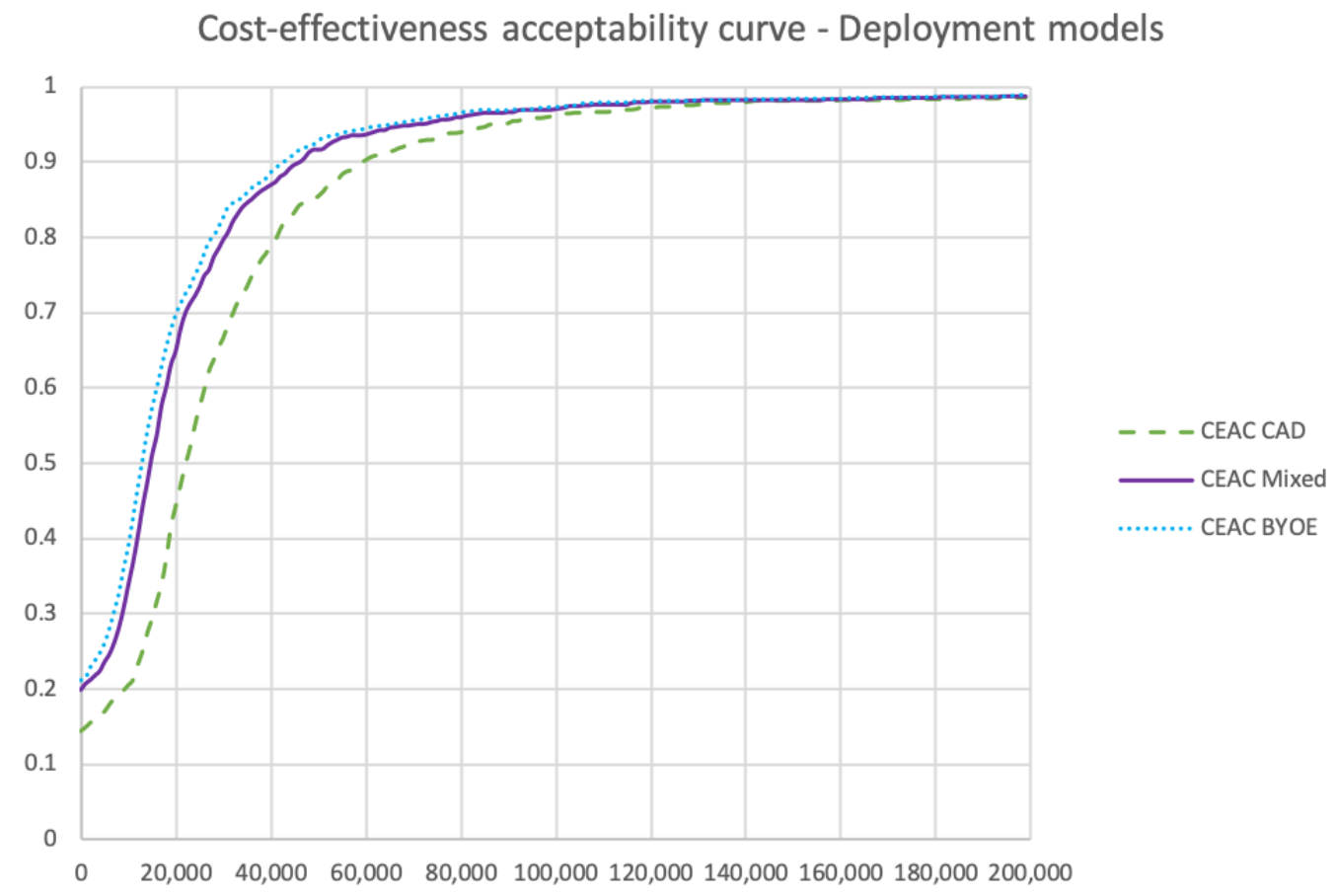

\section{Effectiveness Uncertainty}

When the RR for mortality was set to its lower range, the ICER increased to Can $\$ 18,556$ (US \$13,997.90)/QALY (Table 8). When the RR for mortality was set to its upper range, Medly became dominant (Table 8). When the RR for hospitalization was set to its lower range, Medly became dominant. When the RR for hospitalization was set to its upper range, the ICER increased to Can \$29,240 (US \$22,057.49)/QALY. 
Table 8. Deterministic results for the upper and lower limits of effectiveness in reducing mortality and hospitalization rates.

\begin{tabular}{|c|c|c|c|c|c|c|c|c|c|}
\hline Effectiveness & $\begin{array}{l}\text { Costs (Can } \\
\$)\end{array}$ & $\begin{array}{l}\operatorname{MCSE}^{\mathrm{a}}(\mathrm{Can} \\
\$)\end{array}$ & QALYs $^{\mathrm{b}}$ & MCSE & $\begin{array}{l}\text { Incremental } \\
\text { cost (Can \$) }\end{array}$ & $\begin{array}{l}\text { MCSE (Can } \\
\$)\end{array}$ & $\begin{array}{l}\text { Incremental } \\
\text { QALYs }\end{array}$ & MCSE & $\begin{array}{l}\operatorname{ICER}^{\mathrm{c}}(\mathrm{Can} \\
\text { \$/QALY) }\end{array}$ \\
\hline \multicolumn{10}{|l|}{$R^{d}$ for mortality } \\
\hline \multicolumn{10}{|l|}{$\mathbf{R R}=\mathbf{0 . 7 0}$} \\
\hline Comparator & 97,497 & 3948 & 4.95 & 0.12 & $\underline{\mathrm{e}}^{\mathrm{e}}$ & - & - & - & - \\
\hline Medly & 114,682 & 3995 & 5.87 & 0.13 & 17,186 & 2660 & 0.93 & 0.07 & 18,556 \\
\hline \multicolumn{10}{|l|}{$R R=0.94$} \\
\hline Comparator & 97,497 & 3948 & 4.95 & 0.12 & - & - & - & - & - \\
\hline Medly & 91,542 & 3410 & 5.14 & 0.12 & -5955 & 1339 & 0.19 & 0.03 & $-30,806$ \\
\hline \multicolumn{10}{|l|}{ RR for hospitalization } \\
\hline Comparator & 97,497 & 3948 & 4.95 & 0.12 & - & - & - & - & - \\
\hline Medly & 92,107 & 3176 & 5.55 & 0.13 & -5390 & 2126 & 0.61 & 0.06 & -8895 \\
\hline \multicolumn{10}{|l|}{$\mathrm{RR}=\mathbf{0 . 8 8}$} \\
\hline Comparator & 97,497 & 3948 & 4.95 & 0.12 & - & - & - & - & - \\
\hline Medly & 113,763 & 4052 & 5.50 & 0.13 & 16,267 & 2104 & 0.56 & 0.028 & 29,240 \\
\hline
\end{tabular}

${ }^{\mathrm{a}} \mathrm{MCSE}$ : Monte Carlo standard error.

${ }^{\mathrm{b}} \mathrm{QALY}$ : quality-adjusted life year.

${ }^{\mathrm{c}}$ ICER: incremental cost-effectiveness ratio.

${ }^{\mathrm{d}} \mathrm{RR}$ : relative risk.

${ }^{\mathrm{e}} \mathrm{N} / \mathrm{A}$ : not applicable.

\section{Discussion}

\section{Principal Findings}

The purpose of this study was to assess the cost utility of the Medly program for patients with HF compared with the standard of care from a public payer perspective. The analysis showed that Medly had a high probability $(90.1 \%)$ of being cost-effective at a WTP threshold of Can \$50,000 (US $\$ 37,718) / \mathrm{QALY}$. The results also showed that cost-effectiveness improved in cohorts with more advanced HF. This is attributable to the higher health care utilization rates experienced in higher NYHA functional classes. Deployment models with larger proportions of patients bringing their own equipment to the Medly program were also shown to be more cost-effective owing to lower costs incurred by the program itself. Furthermore, the model itself was sensitive to the effectiveness parameters that informed the magnitude of the decrease in all-cause hospitalizations and mortality. However, the results of these analyses showed that Medly remains cost-effective even in scenarios with smaller clinical benefit, assuming a WTP threshold of Can $\$ 50,000$ (US \$37,718)/QALY [79,80].

\section{Study Implications}

The significance of the study findings are 3-fold: (1) providing evidence for health care decision makers on the use of TM for $\mathrm{HF}$, (2) supporting the use of a nurse-led model of TM using clinically validated algorithms within HF clinics, and (3) informing the use of economic modeling for future evaluation of early-stage health informatics technology.
Our study provided the Medly program with its first evaluation, where an economic perspective was considered. This added to the growing body of evidence associated with the program's value not only for patients and health care professionals but also for the health care system. As discussions about implementing the Medly program at other sites in Ontario continue among decision makers and stakeholders, this study directly contributes to their understanding of Medly's cost-effectiveness. It enables a new perspective on the upfront costs involved with implementing the TM infrastructure and purchasing necessary equipment, relative to the total costs a patient with HF incurs over a lifetime. Such evidence alleviates some of the uncertainty around the risks in introducing a new model of care for patients with HF.

A key factor contributing to the cost-effectiveness of Medly was the high number of patients (500) that a single nurse could manage, which is possible owing to the clinically validated algorithms that generate automatic clinical alerts and self-care messages. Other studies have reported a concern regarding increased clinical workload associated with incompatibility of the TM program with existing workflows, including management of and responding to alerts [81-83]. To mitigate the increased physician workload, the Medly program relies on a registered nurse coordinator and a rule-based algorithm [46] as a patient's first point of contact, decreasing dependency on cardiologists. The registered nurse had the necessary skills to manage patient concerns and involved cardiologists as required. This nurse-led strategy presents a model of care that could be scalable to other hospitals. 
Our study provides a case study on the use of multiple data sources and methods to develop a decision model for an early-stage health informatics intervention where knowledge gaps existed. As the purpose of this study was to evaluate the potential long-term effects of the Medly program in the management of patients with HF, the use of various data sources and modeling techniques are indispensable. This study was successful in developing a flexible algorithm based on the Cholesky decomposition method that was able to generate representative hypothetical cohorts of patients with HF according to the needs of the analysis [56]. An example of the algorithm's flexibility to adapt to the needs of the analyses was the ability to generate hypothetical patient cohorts for NYHA classes I, II, and III while maintaining the individual differences between patients within each class. Our study also successfully implemented a highly validated multivariate Cox model, the SHFM [42-45], within our algorithm to predict the survival of each generated patient over their lifetime. As the purpose of this study was to understand the long-term effects of the Medly program, the inclusion of the most validated predictive model for HF survival was logical [84]. The use of the SHFM provided a link for the survival probabilities derived in our model to a larger body HF research around predictive modeling. As mentioned, this was similar to the study by Reed et al (2015) [42], in which the SHFM was used as its underlying prognosis model and correlated health care costs and utility values via regression techniques $[42,85,86]$.

\section{Comparison With Other Work}

Other studies have investigated the cost-effectiveness of other types of TM in HF, where data are transmitted to medical staff. The study by Thokala et al (2013) [38] compared TM with usual care from the public payer perspective and found TM to be cost-effective at $£ 11,873 / \mathrm{QALY}$ gained in 2011 (equivalent to Can $\$ 19,996$ (US \$15,084.18)/QALY gained in 2018) using a two-state (alive or dead) cohort-based Markov model over a 30-year time horizon. This relatively higher ICER than ICER in our study, which could be attributed to various factors, such as the lower cost of hospitalizations (£1529.97-£2514.49), led to less cost-saving per hospitalization. Furthermore, model structures differed between the study by Thokala et al [38] and our study, in which different health states and transition probabilities were used. A study by Liu et al (2016) [40] also broadly compared TM with standard care from the payer perspective in the United States and found cost-savings for specific scenarios. This included patients who were intermediate and high-risk over 1- to 5-year time horizons. These results differ from our study owing to different model structures and transition probability parameters. The health states in the model developed by Liu et al (2016) were based on the number of past hospitalizations. In addition, hospitalization rates were conditional on both NYHA functional class and number of past hospitalizations, where the associated monthly probabilities for hospitalizations were much higher than those used in our study. This increased rate of hospitalizations in combination with the larger treatment effect size in reducing mortality and hospitalizations can be attributed to the cost-saving results [40]. A study by Grustam et al (2018) [39] compared TM with usual care for patients with HF from the public payer perspective within the Trans-European Network-Home-Care Management System using data from its original publication and other sources. This resulted in an ICER of $€ 12,479 / \mathrm{QALY}$ gained in 2015 (Can $\$ 18,145$ [US \$13,687.86] in 2018), which was relatively higher than that reported in our study. The difference in our results can be attributed to the different methods used to model HF and measure effectiveness. The effectiveness of TM in the study was not defined by the risk for all-cause mortality and hospitalization events. Rather, effectiveness was measured by the decrease in probabilities of transitioning to more severe NYHA functional classes and the dead state based on an extrapolation from their database of patients with HF using TM [39].

\section{Limitations}

As with any modeling exercise, it is important to understand the limitations around data availability and assumptions. First, owing to the lack of long-term studies, the trajectory of the effectiveness of TM was unknown and was assumed constant over the patient's lifetime. It is not known if effectiveness changes over time, which may affect the results of this study. Another limitation was the assumption that patients used Medly over the entirety of the model. It has been reported that clinicians have not established a generalizable duration of enrollment into the program [87]. Patients may be enrolled into the program for a period of time and be off-boarded after they have learned the necessary self-care behaviors for $\mathrm{HF}$ and no longer require the assistance of the technology. This could decrease the costs of the intervention. In addition, caution should be exercised when interpreting data from the Medly program evaluation because patients are enrolled in the program based on a joint decision between the clinician and the patient, which could lead to selection bias. Without strict enrollment criteria and end time points, patients may be less sick than the average patients with $\mathrm{HF}$, making results less generalizable. Another limitation was that it was assumed that the QoL of patients using Medly was same as that of patients in the comparator group. However, evidence from the Medly program evaluation [47] and past literature [88] indicates that QoL improves when patients use Medly. As QoL in these studies was measured using HF-specific scoring tools, translation of the improved QoL to utility values used in this study was not feasible because the QALY is derived from the EuroQol-5 Dimension instrument [89]. This likely underestimated Medly's total QALYs gained. In addition, health care utilization data used to inform parameters in this study were based on the Medly program evaluation, which relied on a relatively small sample of patients, self-reported ED and GP visits, and a database that was limited to events that occurred at 1 hospital. This early-stage evidence on baseline health care utilization in patients with $\mathrm{HF}$ may underestimate or overestimate the actual health care utilization of an $\mathrm{HF}$ population, which could alter the results of the study.

\section{Conclusions}

The Medly program was found to be a cost-effective solution given the widely cited WTP thresholds of Can $\$ 50,000$ (US $\$ 37,718$ )/QALY for patients with HF when implemented within a multidisciplinary HF clinic in Ontario. This is the first Canadian economic evaluation of TM for HF using a cost-utility 
approach, and one of the few studies to use a long-term time horizon. The significance of this study includes providing evidence for health care decision makers on the use of TM for HF, supporting the use of a nurse-led model of TM within HF clinics, and informing the use of economic modeling for future evaluations of early-stage health informatics technology. Given the substantial impact of HF on patients' QoL and burden on health care resources, expanding access to TM programs may be an important mechanism to improve HF disease management and patient outcomes.

\section{Conflicts of Interest}

HR and ES are considered inventors of the Medly system under the intellectual property policies of the UHN and may benefit from future commercialization of the technology by UHN.

\section{Multimedia Appendix 1}

Additional methodology supplementary material.

[DOCX File , 62 KB-Multimedia Appendix 1]

\section{References}

1. Savarese G, Lund LH. Global public health burden of heart failure. Card Fail Rev 2017 Apr;3(1):7-11 [FREE Full text] [doi: 10.15420/cfr.2016:25:2] [Medline: 28785469]

2. Heart disease in Canada: Highlights from the Canadian Chronic Disease Surveillance System. Government of Canada. 2020. URL: https://www.canada.ca/en/public-health/services/publications/diseases-conditions/heart-disease-canada-fact-sheet. html [accessed 2020-09-15]

3. Taylor CJ. Trends in survival after a diagnosis of heart failure in the United Kingdom 2000-2017: population based cohort study. Br Med J 2019 Oct 8;367:15840 [FREE Full text] [doi: 10.1136/bmj.15840] [Medline: 31594775]

4. Taylor CJ, Ryan R, Nichols L, Gale N, Hobbs FR, Marshall T. Survival following a diagnosis of heart failure in primary care. Fam Pract 2017 Apr 1;34(2):161-168 [FREE Full text] [doi: 10.1093/fampra/cmw145] [Medline: 28137979]

5. Gerber Y, Weston SA, Redfield MM, Chamberlain AM, Manemann SM, Jiang R, et al. A contemporary appraisal of the heart failure epidemic in Olmsted County, Minnesota, 2000 to 2010. JAMA Intern Med 2015 Jun;175(6):996-1004 [FREE Full text] [doi: 10.1001/jamainternmed.2015.0924] [Medline: 25895156]

6. Chun S, Tu JV, Wijeysundera HC, Austin PC, Wang X, Levy D, et al. Lifetime analysis of hospitalizations and survival of patients newly admitted with heart failure. Circ Heart Fail 2012 Jul 1;5(4):414-421 [FREE Full text] [doi: 10.1161/CIRCHEARTFAILURE.111.964791] [Medline: 22556322]

7. Desai AS, Stevenson LW. Rehospitalization for heart failure: predict or prevent? Circulation 2012 Jul 24;126(4):501-506. [doi: 10.1161/CIRCULATIONAHA.112.125435] [Medline: 22825412]

8. Tran DT, Ohinmaa A, Thanh NX, Howlett JG, Ezekowitz JA, McAlister FA, et al. The current and future financial burden of hospital admissions for heart failure in Canada: a cost analysis. CMAJ Open 2016;4(3):E365-E370 [REEE Full text] [doi: 10.9778/cmajo.20150130] [Medline: 27730101]

9. Virani SA, Bains M, Code J, Ducharme A, Harkness K, Howlett JG, Board and Membership of the Canadian Heart Failure Society. The need for heart failure advocacy in Canada. Can J Cardiol 2017 Nov;33(11):1450-1454. [doi: 10.1016/j.cjca.2017.08.024] [Medline: 29111108 ]

10. Lin M, Yuan W, Huang T, Zhang H, Mai J, Wang J. Clinical effectiveness of telemedicine for chronic heart failure: a systematic review and meta-analysis. J Investig Med 2017 Jun;65(5):899-911. [doi: 10.1136/jim-2016-000199] [Medline: $\underline{28330835]}$

11. Yun JE, Park J, Park H, Lee H, Park D. Comparative effectiveness of telemonitoring versus usual care for heart failure: a systematic review and meta-analysis. J Card Fail 2018 Jan;24(1):19-28. [doi: 10.1016/j.cardfail.2017.09.006] [Medline: $\underline{28939459]}$

12. Kitsiou S, Paré G, Jaana M. Effects of home telemonitoring interventions on patients with chronic heart failure: an overview of systematic reviews. J Med Internet Res 2015 Mar 12;17(3):e63 [FREE Full text] [doi: 10.2196/jmir.4174] [Medline: 25768664]

13. Nakamura N, Koga T, Iseki H. A meta-analysis of remote patient monitoring for chronic heart failure patients. J Telemed Telecare 2014 Jan;20(1):11-17. [doi: 10.1177/1357633X13517352] [Medline: 24352899]

14. Xiang R, Li L, Liu SX. Meta-analysis and meta-regression of telehealth programmes for patients with chronic heart failure. J Telemed Telecare 2013 Jul;19(5):249-259. [doi: 10.1177/1357633X13495490] [Medline: 24163234]

15. Ong MK, Romano PS, Edgington S, Aronow HU, Auerbach AD, Black JT, Better Effectiveness After Transition-Heart Failure (BEAT-HF) Research Group. Effectiveness of remote patient monitoring after discharge of hospitalized patients with heart failure: the better effectiveness after transition -- heart failure (BEAT-HF) randomized clinical trial. JAMA Intern Med 2016 Mar;176(3):310-318 [FREE Full text] [doi: 10.1001/jamainternmed.2015.7712] [Medline: 26857383]

16. Chaudhry SI, Mattera JA, Curtis JP, Spertus JA, Herrin J, Lin Z, et al. Telemonitoring in patients with heart failure. N Engl J Med 2010 Dec 9;363(24):2301-2309. [doi: 10.1056/nejmoa1010029] 
17. Koehler F, Koehler K, Deckwart O, Prescher S, Wegscheider K, Kirwan B, et al. Efficacy of telemedical interventional management in patients with heart failure (TIM-HF2): a randomised, controlled, parallel-group, unmasked trial. Lancet 2018 Sep;392(10152):1047-1057. [doi: 10.1016/s0140-6736(18)31880-4]

18. Koehler F, Winkler S, Schieber M, Sechtem U, Stangl K, Böhm M, Telemedical Interventional Monitoring in Heart Failure Investigators. Impact of remote telemedical management on mortality and hospitalizations in ambulatory patients with chronic heart failure: the telemedical interventional monitoring in heart failure study. Circulation 2011 May 3;123(17):1873-1880. [doi: 10.1161/CIRCULATIONAHA.111.018473] [Medline: 21444883]

19. Ware P, Seto E, Ross HJ. Accounting for complexity in home telemonitoring: a need for context-centred evidence. Can J Cardiol 2018 Jul;34(7):897-904. [doi: 10.1016/j.cjca.2018.01.022] [Medline: 29861204]

20. Dávalos ME, French MT, Burdick AE, Simmons SC. Economic evaluation of telemedicine: review of the literature and research guidelines for benefit-cost analysis. Telemed J E Health 2009 Dec;15(10):933-948. [doi: 10.1089/tmj.2009.0067] [Medline: 19954346]

21. Bergmo TS. Approaches to economic evaluation in telemedicine. J Telemed Telecare 2012 Jun;18(4):181-184. [doi: 10.1258/jtt.2012.111112] [Medline: 22619374]

22. Noel HC, Vogel DC, Erdos JJ, Cornwall D, Levin F. Home telehealth reduces healthcare costs. Telemed J E Health 2004;10(2):170-183. [doi: 10.1089/tmj.2004.10.170] [Medline: 15319047 ]

23. Myers S, Grant RW, Lugn NE, Holbert B, Kvedar JC. Impact of home-based monitoring on the care of patients with congestive heart failure. Home Health Care Manag Pract 2016 Jun 30;18(6):444-451. [doi: 10.1177/1084822306289991]

24. Hudson LR, Hamar GB, Orr P, Johnson JH, Neftzger A, Chung RS, et al. Remote physiological monitoring: clinical, financial, and behavioral outcomes in a heart failure population. Dis Manag 2005 Dec;8(6):372-381. [doi: 10.1089/dis.2005.8.372] [Medline: 16351555$]$

25. Giordano A, Scalvini S, Zanelli E, Corrà U, Longobardi GL, Ricci VA, et al. Multicenter randomised trial on home-based telemanagement to prevent hospital readmission of patients with chronic heart failure. Int J Cardiol 2009 Jan 9;131(2):192-199. [doi: 10.1016/j.ijcard.2007.10.027] [Medline: 18222552]

26. Scalvini S, Capomolla S, Zanelli E, Benigno M, Domenighini D, Paletta L, et al. Effect of home-based telecardiology on chronic heart failure: costs and outcomes. J Telemed Telecare 2005;11(Suppl 1):16-18. [doi: 10.1258/1357633054461688] [Medline: 16035980]

27. Vaccaro J, Cherry J, Harper A, O'Connell M. Utilization reduction, cost savings, and return on investment for the pacificare chronic heart failure program, 'taking charge of your heart health'. Disease Manag 2001 Sep;4(3):131-142. [doi: $10.1089 / 10935070152596052]$

28. Galbreath AD, Krasuski RA, Smith B, Stajduhar KC, Kwan MD, Ellis R, et al. Long-term healthcare and cost outcomes of disease management in a large, randomized, community-based population with heart failure. Circulation 2004 Dec 7;110(23):3518-3526. [doi: 10.1161/01.CIR.0000148957.62328.89] [Medline: 15531765]

29. Schwarz KA, Mion L, Hudock D, Litman G. Telemonitoring of heart failure patients and their caregivers: a pilot randomized controlled trial. Prog Cardiovasc Nurs 2008;23(1):18-26. [doi: 10.1111/j.1751-7117.2008.06611.x] [Medline: $\underline{18326990]}$

30. Soran OZ, Feldman AM, Piña IL, Lamas GA, Kelsey SF, Selzer F, et al. Cost of medical services in older patients with heart failure: those receiving enhanced monitoring using a computer-based telephonic monitoring system compared with those in usual care: the heart failure home care trial. J Card Fail 2010 Nov;16(11):859-866. [doi:

10.1016/j.cardfail.2010.05.028] [Medline: 21055649]

31. Tompkins C, Orwat J. A randomized trial of telemonitoring heart failure patients. J Healthc Manag 2010;55(5):312-22; discussion 322. [Medline: 21077581]

32. Kenealy TW, Parsons MJ, Rouse AP, Doughty RN, Sheridan NF, Hindmarsh JK, et al. Telecare for diabetes, CHF or COPD: effect on quality of life, hospital use and costs. A randomised controlled trial and qualitative evaluation. PLoS One 2015;10(3):e0116188 [FREE Full text] [doi: 10.1371/journal.pone.0116188] [Medline: 25768023]

33. Paré G, Poba-Nzaou P, Sicotte C. Home telemonitoring for chronic disease management: an economic assessment. Int J Technol Assess Health Care 2013 Apr;29(2):155-161. [doi: 10.1017/S0266462313000111] [Medline: 23514722]

34. Methods for the Economic Evaluation of Health Care Programmes. Oxford, UK: Oxford University Press; 2005.

35. Smith B, Hughes-Cromwick P, Forkner E, Galbreath A. Cost-effectiveness of telephonic disease management in heart failure. Am J Manag Care 2008 Feb;14(2):106-115 [FREE Full text] [Medline: 18269306]

36. Klersy C, de Silvestri A, Gabutti G, Raisaro A, Curti M, Regoli F, et al. Economic impact of remote patient monitoring: an integrated economic model derived from a meta-analysis of randomized controlled trials in heart failure. Eur J Heart Fail 2011 Apr;13(4):450-459 [FREE Full text] [doi: 10.1093/eurjhf/hfq232] [Medline: 21193439]

37. Cui Y, Doupe M, Katz A, Nyhof P, Forget E. Economic evaluation of Manitoba Health Lines in the management of congestive heart failure. Healthc Policy 2013 Nov;9(2):36-50 [FREE Full text] [Medline: 24359716]

38. Thokala P, Baalbaki H, Brennan A, Pandor A, Stevens JW, Gomersall T, et al. Telemonitoring after discharge from hospital with heart failure: cost-effectiveness modelling of alternative service designs. BMJ Open 2013 Sep 18;3(9):e003250 [FREE Full text] [doi: 10.1136/bmjopen-2013-003250] [Medline: 24048626] 
39. Grustam AS, Severens JL, de Massari D, Buyukkaramikli N, Koymans R, Vrijhoef HJ. Cost-effectiveness analysis in telehealth: a comparison between home telemonitoring, nurse telephone support, and usual care in chronic heart failure management. Value Health 2018 Jul;21(7):772-782 [FREE Full text] [doi: 10.1016/j.jval.2017.11.011] [Medline: 30005749]

40. Liu SX, Xiang R, Lagor C, Liu N, Sullivan K. Economic modeling of heart failure telehealth programs: when do they become cost saving? Int J Telemed Appl 2016;2016:3289628 [FREE Full text] [doi: 10.1155/2016/3289628] [Medline: $\underline{27528868}]$

41. Husereau D, Drummond M, Petrou S, Carswell C, Moher D, Greenberg D, ISPOR Health Economic Evaluation Publication Guidelines-CHEERS Good Reporting Practices Task Force. Consolidated health economic evaluation reporting standards (cheers)--explanation and elaboration: a report of the ISOPR health economic evaluation publication guidelines good reporting practices task force. Value Health 2013;16(2):231-250 [FREE Full text] [doi: 10.1016/j.jval.2013.02.002] [Medline: 23538175]

42. Reed SD, Neilson MP, Gardner M, Li Y, Briggs AH, Polsky DE, et al. Tools for economic analysis of patient management interventions in heart failure cost-effectiveness model: a web-based program designed to evaluate the cost-effectiveness of disease management programs in heart failure. Am Heart J 2015 Nov;170(5):951-960 [FREE Full text] [doi: 10.1016/j.ahj.2015.08.015] [Medline: 26542504]

43. Levy WC, Mozaffarian D, Linker DT, Sutradhar SC, Anker SD, Cropp AB, et al. The Seattle heart failure model: prediction of survival in heart failure. Circulation 2006 Mar 21;113(11):1424-1433. [doi: 10.1161/CIRCULATIONAHA.105.584102] [Medline: 16534009]

44. Kalogeropoulos AP, Georgiopoulou VV, Giamouzis G, Smith AL, Agha SA, Waheed S, et al. Utility of the Seattle Heart Failure Model in patients with advanced heart failure. J Am Coll Cardiol 2009 Jan 27;53(4):334-342 [FREE Full text] [doi: 10.1016/j.jacc.2008.10.023] [Medline: 19161882]

45. Ketchum ES, Moorman AJ, Fishbein DP, Mokadam NA, Verrier ED, Aldea GS, et al. Predictive value of the Seattle Heart Failure Model in patients undergoing left ventricular assist device placement. J Heart Lung Transplant 2010 Sep;29(9):1021-1025. [doi: 10.1016/j.healun.2010.05.002] [Medline: 20558086]

46. Seto E, Leonard KJ, Cafazzo JA, Barnsley J, Masino C, Ross HJ. Developing healthcare rule-based expert systems: case study of a heart failure telemonitoring system. Int J Med Inform 2012 Aug;81(8):556-565. [doi:

10.1016/j.ijmedinf.2012.03.001] [Medline: 22465288]

47. Ware P, Ross HJ, Cafazzo JA, Boodoo C, Munnery M, Seto E. Outcomes of a heart failure telemonitoring program implemented as the standard of care in an outpatient heart function clinic: pretest-posttest pragmatic study. J Med Internet Res 2020 Feb 8;22(2):e16538 [FREE Full text] [doi: 10.2196/16538] [Medline: 32027309]

48. Wijeysundera HC, Trubiani G, Abrahamyan L, Mitsakakis N, Witteman W, Paulden M, et al. Specialized multi-disciplinary heart failure clinics in Ontario, Canada: an environmental scan. BMC Health Serv Res 2012 Aug 3;12:236 [ㅍREE Full text] [doi: 10.1186/1472-6963-12-236] [Medline: 22863276]

49. Guidelines for the Economic Evaluation of Health Technologies: Canada. Canadian Agency for Drugs and Technologies in Health (CADTH). 2017. URL: https://www.cadth.ca/about-cadth/how-we-do-it/methods-and-guidelines/ guidelines-for-the-economic-evaluation-of-health-technologies-canada [accessed 2020-09-15]

50. Krijkamp EM, Alarid-Escudero F, Enns EA, Jalal HJ, Hunink MG, Pechlivanoglou P. Microsimulation modeling for health decision sciences using R: a tutorial. Med Decis Making 2018 Apr;38(3):400-422 [FREE Full text] [doi:

10.1177/0272989X18754513] [Medline: 29587047]

51. Nomenclature and Criteria for Diagnosis of Diseases of the Heart and Great Vessels. Boston, UK: Martin Dolgin; 1994.

52. Desai AS. The three-phase terrain of heart failure readmissions. Circ Heart Fail 2012 Jul 1;5(4):398-400. [doi: 10.1161/CIRCHEARTFAILURE.112.968735] [Medline: 22811548]

53. Giamouzis G, Kalogeropoulos A, Georgiopoulou V, Laskar S, Smith AL, Dunbar S, et al. Hospitalization epidemic in patients with heart failure: risk factors, risk prediction, knowledge gaps, and future directions. J Card Fail 2011 Jan;17(1):54-75. [doi: 10.1016/j.cardfail.2010.08.010] [Medline: 21187265]

54. Canadian Institute for Health Information (CIHI). All-Cause Readmission to Acute Care and Return to the Emergency Department. 2020. URL: https://secure.cihi.ca/free products/Readmission to acutecare en.pdf [accessed 2020-09-15]

55. Naimark DM, Kabboul NN, Krahn MD. The half-cycle correction revisited: redemption of a kludge. Med Decis Making 2013 Oct;33(7):961-970. [doi: 10.1177/0272989X13501558] [Medline: 24048350]

56. Decision Modelling for Health Economic Evaluation. Oxford, UK: Oxford University Press; 2006.

57. Beta-Blocker Evaluation of Survival Trial Investigators, Eichhorn EJ, Domanski MJ, Krause-Steinrauf H, Bristow MR, Lavori PW. A trial of the beta-blocker bucindolol in patients with advanced chronic heart failure. N Engl J Med 2001 May 31;344(22):1659-1667. [doi: 10.1056/NEJM200105313442202] [Medline: 11386264]

58. Chan DC, Heidenreich PA, Weinstein MC, Fonarow GC. Heart failure disease management programs: a cost-effectiveness analysis. Am Heart J 2008 Feb;155(2):332-338. [doi: 10.1016/j.ahj.2007.10.001] [Medline: 18215605]

59. Delea TE, Vera-Llonch M, Richner RE, Fowler MB, Oster G. Cost effectiveness of carvedilol for heart failure. Am J Cardiol 1999 Mar;83(6):890-896 [FREE Full text] [doi: 10.1016/s0002-9149(98)01066-2]

60. Göhler A, Geisler BP, Manne JM, Kosiborod M, Zhang Z, Weintraub WS, et al. Utility estimates for decision-analytic modeling in chronic heart failure--health states based on New York Heart Association classes and number of 
rehospitalizations. Value Health 2009;12(1):185-187 [FREE Full text] [doi: 10.1111/j.1524-4733.2008.00425.x] [Medline: $\underline{18647251]}$

61. Ahmed A, Aronow WS, Fleg JL. Higher New York Heart Association classes and increased mortality and hospitalization in patients with heart failure and preserved left ventricular function. Am Heart J 2006 Feb;151(2):444-450 [FREE Full text] [doi: 10.1016/j.ahj.2005.03.066] [Medline: 16442912]

62. Yao B, Freemantle N, Tharmanathan P, Coats A, Poole-Wilson PA. Long-term cost-effectiveness analysis of nebivolol compared with standard care in elderly patients with heart failure: an individual patient-based simulation model. Pharmacoecon Open 2008;26(10):879-889 [ [FREE Full text] [doi: 10.1186/1471-2105-5-99] [Medline: 15272935]

63. Flather MD, Shibata MC, Coats AJ, van Veldhuisen DJ, Parkhomenko A, Borbola J, SENIORS Investigators. Randomized trial to determine the effect of nebivolol on mortality and cardiovascular hospital admission in elderly patients with heart failure (SENIORS). Eur Heart J 2005 Feb;26(3):215-225. [doi: 10.1093/eurheartj/ehi115] [Medline: 15642700]

64. Yeung DF, Boom NK, Guo H, Lee DS, Schultz SE, Tu JV. Trends in the incidence and outcomes of heart failure in Ontario, Canada: 1997 to 2007. Can Med Assoc J 2012 Oct 2;184(14):E765-E773 [FREE Full text] [doi: 10.1503/cmaj.111958] [Medline: 22908143]

65. Reed SD, Neilson MP, Gardner M, Li Y, Briggs AH, Polsky DE, et al. Tools for economic analysis of patient management interventions in heart failure cost-effectiveness model: a web-based program designed to evaluate the cost-effectiveness of disease management programs in heart failure. Am Heart J 2015 Nov;170(5):951-960 [FREE Full text] [doi: 10.1016/j.ahj.2015.08.015] [Medline: 26542504]

66. Amatya A, Demirtas H. Simultaneous generation of multivariate mixed data with Poisson and normal marginals. J Stat Comput Sim 2014 Sep;85(15):3129-3139. [doi: 10.1080/00949655.2014.953534]

67. Demirtas H, Doganay B. Simultaneous generation of binary and normal data with specified marginal and association structures. J Biopharm Stat 2012;22(2):223-236. [doi: 10.1080/10543406.2010.521874] [Medline: 22251171]

68. Ford E, Adams J, Graves N. Development of an economic model to assess the cost-effectiveness of hawthorn extract as an adjunct treatment for heart failure in Australia. BMJ Open 2012;2(5):- [FREE Full text] [doi: 10.1136/bmjopen-2012-001094] [Medline: 22942231]

69. Borisenko O, Haude M, Hoppe UC, Siminiak T, Lipiecki J, Goldberg SL, et al. Cost-utility analysis of percutaneous mitral valve repair in inoperable patients with functional mitral regurgitation in German settings. BMC Cardiovasc Disord 2015 May 14;15:43 [FREE Full text] [doi: 10.1186/s12872-015-0039-8] [Medline: 25971307]

70. Jaagosild P, Dawson NV, Thomas C, Wenger NS, Tsevat J, Knaus WA, et al. Outcomes of acute exacerbation of severe congestive heart failure: quality of life, resource use, and survival. Support investigators. The study to understand prognosis and preferences for outcomes and risks of treatments. Arch Intern Med 1998 May 25;158(10):1081-1089. [doi: 10.1001/archinte.158.10.1081] [Medline: 9605779]

71. Sandhu AT, Goldhaber-Fiebert JD, Owens DK, Turakhia MP, Kaiser DW, Heidenreich PA. Cost-effectiveness of implantable pulmonary artery pressure monitoring in chronic heart failure. JACC Heart Fail 2016 May;4(5):368-375 [FREE Full text] [doi: 10.1016/j.jchf.2015.12.015] [Medline: 26874380]

72. Kaul P, McAlister FA, Ezekowitz JA, Bakal JA, Curtis LH, Quan H, et al. Resource use in the last 6 months of life among patients with heart failure in Canada. Arch Intern Med 2011 Feb 14;171(3):211-217. [doi: 10.1001/archinternmed.2010.365] [Medline: 20937918]

73. Costing Analysis Tool. Ontario Case Costing. 2019. URL: https://www.engenderhealth.org/files/pubs/qi/toolbook/ cost_analysis_tool.pdf [accessed 2020-09-15]

74. Schedule of Benefits: Physician Services Under the Health Insurance Act. Ministry of Health and Long Term Care. URL: http://govdocs.ourontario.ca/node/2924 [accessed 2020-09-15]

75. Health Costing in Alberta 2006: Annual Report. Alberta Health and Wellness. 2006. URL: https://www.assembly.ab.ca/ lao/library/egovdocs/2006/alhw/129693 06.pdf [accessed 2020-09-15]

76. Mihaylova B, Briggs A, O'Hagan A, Thompson SG. Review of statistical methods for analysing healthcare resources and costs. Health Econ 2011 Aug;20(8):897-916 [FREE Full text] [doi: 10.1002/hec.1653] [Medline: 20799344]

77. The Canadian Consumer Price Index Reference Paper. Statistics Canada. 2019. URL: https://www150.statcan.gc.ca/n1/ pub/62-553-x/62-553-x2015001-eng.pdf [accessed 2020-09-15]

78. Delignette-Muller ML, Dutang C. An R package for fitting distributions. J Stat Soft 2015;64(4):-. [doi: 10.18637/jss.v064.i04]

79. Valuing Health in Canada: Who, How, and How Much. Canada 2020. 2013. URL: http://canada2020.ca/wp-content/uploads/ 2013/06/Canada-2020-Analytical-Commentary-No-3-Valuing-Health-in-Canada-FINAL.pdf [accessed 2020-09-15]

80. Laupacis A, Feeny D, Detsky AS, Tugwell PX. How attractive does a new technology have to be to warrant adoption and utilization? Tentative guidelines for using clinical and economic evaluations. Can Med Assoc J 1992 Feb 15;146(4):473-481 [FREE Full text] [Medline: 1306034]

81. Seto E, Leonard KJ, Masino C, Cafazzo JA, Barnsley J, Ross HJ. Attitudes of heart failure patients and health care providers towards mobile phone-based remote monitoring. J Med Internet Res 2010 Nov 29;12(4):e55 [FREE Full text] [doi: 10.2196/jmir.1627] [Medline: 21115435] 
82. Seto E, Leonard KJ, Cafazzo JA, Barnsley J, Masino C, Ross HJ. Perceptions and experiences of heart failure patients and clinicians on the use of mobile phone-based telemonitoring. J Med Internet Res 2012 Feb 10;14(1):e25 [FREE Full text] [doi: 10.2196/jmir.1912] [Medline: 22328237]

83. Ware P, Ross HJ, Cafazzo JA, Laporte A, Gordon K, Seto E. Evaluating the implementation of a mobile phone-based telemonitoring program: longitudinal study guided by the consolidated framework for implementation research. JMIR Mhealth Uhealth 2018 Jul 31;6(7):e10768 [FREE Full text] [doi: 10.2196/10768] [Medline: 30064970]

84. Alba AC, Agoritsas T, Jankowski M, Courvoisier D, Walter SD, Guyatt GH, et al. Risk prediction models for mortality in ambulatory patients with heart failure: a systematic review. Circ Heart Fail 2013 Sep 1;6(5):881-889. [doi: 10.1161/CIRCHEARTFAILURE.112.000043] [Medline: 23888045]

85. Li Y, Neilson MP, Whellan DJ, Schulman KA, Levy WC, Reed SD. Associations between Seattle Heart Failure Model scores and health utilities: findings from HF-ACTION. J Card Fail 2013 May;19(5):311-316 [FREE Full text] [doi: 10.1016/j.cardfail.2013.03.008] [Medline: 23663813]

86. Reed SD, Li Y, Ellis SJ, Whellan DJ, Schulman KA, O'Connor CM, et al. Seattle heart failure model scores significantly predict medical resource use and costs in HF-action. J Card Fail 2011 Aug;17(8):S80. [doi: 10.1016/j.cardfail.2011.06.272]

87. Ware P, Ross HJ, Cafazzo JA, Laporte A, Gordon K, Seto E. User-centered adaptation of an existing heart failure telemonitoring program to ensure sustainability and scalability: qualitative study. JMIR Cardio 2018 Dec 6;2(2):e11466 [FREE Full text] [doi: 10.2196/11466] [Medline: 31758774]

88. Seto E, Leonard KJ, Cafazzo JA, Barnsley J, Masino C, Ross HJ. Mobile phone-based telemonitoring for heart failure management: a randomized controlled trial. J Med Internet Res 2012 Feb 16;14(1):e31 [FREE Full text] [doi: 10.2196/jmir.1909] [Medline: 22356799]

89. Xie F, Pullenayegum E, Gaebel K, Bansback N, Bryan S, Ohinmaa A, Canadian EQ-5D-5L Valuation Study Group. A time trade-off-derived value set of the EQ-5D-5L for Canada. Med Care 2016 Jan;54(1):98-105 [FREE Full text] [doi: 10.1097/MLR.0000000000000447] [Medline: 26492214]

\author{
Abbreviations \\ BYOE: Bring Your Own Everything \\ BYOP: Bring Your Own Phone \\ CEAC: cost-effectiveness acceptability curve \\ CUA: cost-utility analysis \\ ED: emergency department \\ FK: Full Kit \\ GP: general practitioner \\ HF: heart failure \\ ICER: incremental cost-effectiveness ratio \\ NYHA: New York Health Association \\ QALY: quality-adjusted life year \\ QoL: quality of life \\ RR: relative risk \\ SHFM: Seattle Heart Failure Model \\ TM: telemonitoring \\ UHN: University Health Network \\ WTP: willingness-to-pay
}

Edited by G Eysenbach; submitted 27.03.20; peer-reviewed by B Chan, $K$ Wei; comments to author 12.06.20; revised version received
05.08.20; accepted 06.08.20; published 06.10.20
Please cite as:
Boodoo C, Zhang Q, Ross HJ, Alba AC, Laporte A, Seto E
Evaluation of a Heart Failure Telemonitoring Program Through a Microsimulation Model: Cost-Utility Analysis
J Med Internet Res 2020;22(10):e18917
URL: $\underline{\text { https://www.jmir.org/2020/10/e18917 }}$
doi: $10.2196 / 18917$
PMID: $\underline{33021485}$

(C) Chris Boodoo, Qi Zhang, Heather J Ross, Ana Carolina Alba, Audrey Laporte, Emily Seto. Originally published in the Journal of Medical Internet Research (http://www.jmir.org), 06.10.2020. This is an open-access article distributed under the terms of the 
Creative Commons Attribution License (https://creativecommons.org/licenses/by/4.0/), which permits unrestricted use, distribution, and reproduction in any medium, provided the original work, first published in the Journal of Medical Internet Research, is properly cited. The complete bibliographic information, a link to the original publication on http://www.jmir.org/, as well as this copyright and license information must be included. 